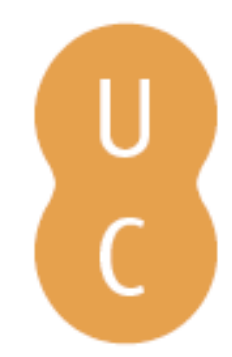

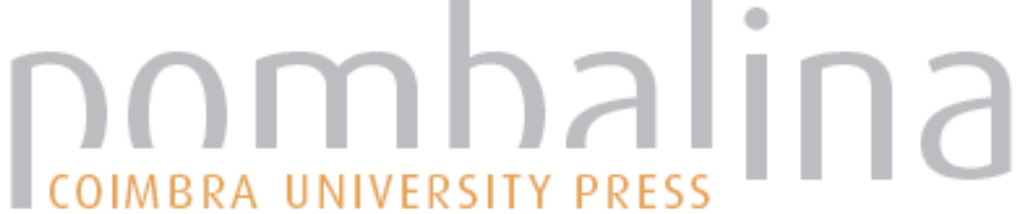

\section{Banquete: apologia de Sócrates}

\author{
Autor(es): Xenofonte \\ Publicado por: Centro de Estudos Clássicos e Humanísticos \\ URL \\ persistente: URI:http://hdl.handle.net/10316.2/2407 \\ DOI: $\quad$ DOI:http://dx.doi.org/10.14195/978-989-721-059-4
}

Accessed : $\quad$ 26-Apr-2023 16:20:16

A navegação consulta e descarregamento dos títulos inseridos nas Bibliotecas Digitais UC Digitalis, UC Pombalina e UC Impactum, pressupõem a aceitação plena e sem reservas dos Termos e Condições de Uso destas Bibliotecas Digitais, disponíveis em https://digitalis.uc.pt/pt-pt/termos.

Conforme exposto nos referidos Termos e Condições de Uso, o descarregamento de títulos de acesso restrito requer uma licença válida de autorização devendo o utilizador aceder ao(s) documento(s) a partir de um endereço de IP da instituição detentora da supramencionada licença.

Ao utilizador é apenas permitido o descarregamento para uso pessoal, pelo que o emprego do(s) título(s) descarregado(s) para outro fim, designadamente comercial, carece de autorização do respetivo autor ou editor da obra.

Na medida em que todas as obras da UC Digitalis se encontram protegidas pelo Código do Direito de Autor e Direitos Conexos e demais legislação aplicável, toda a cópia, parcial ou total, deste documento, nos casos em que é legalmente admitida, deverá conter ou fazer-se acompanhar por este aviso.

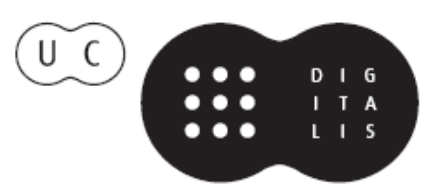




\section{Xenofonte}

\section{BANQUETE}

Apologia De SÓCRATES

TRADUÇÃO DO GREGO, INTRODUÇÃO E NOTAS Ana Elias Pinheiro 
Série "Autores Gregos e Latinos -

TRADUÇÃO, INTRODUÇÁO E COMENTÁRIO”

ISSN: 2183-220X

Apresentação: Esta série procura apresentar em língua portuguesa obras de autores gregos, latinos e neolatinos, em tradução feita diretamente a partir da língua original. Além da tradução, todos os volumes são também caraterizados por conterem estudos introdutórios, bibliografia crítica e notas. Reforça-se, assim, a originalidade científica e o alcance da série, cumprindo o duplo objetivo de tornar acessíveis textos clássicos, medievais e renascentistas a leitores que náo dominam as línguas antigas em que foram escritos. Também do ponto de vista da reflexão académica, a coleçáo se reveste no panorama lusófono de particular importância, pois proporciona contributos originais numa área de investigaçáo científica fundamental no universo geral do conhecimento e divulgaçáo do património literário da Humanidade. 
(Página deixada propositadamente em branco) 


\section{Xenofonte}

\section{Banquete \\ Apologia de Sócrates}

TraduÇão Do GREGo, INTRODUÇÃo E NOTAS DE

Ana Elias Pinheiro

Universidade Católica Portuguesa - Campus Viseu

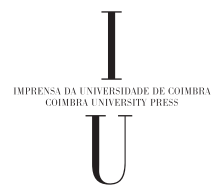


Autor: Xenofonte

Título: BANQUETE, APOLOGIa DE Sócrates

Traduçấo do grego, introduçấo e notas: Ana Elias Pinheiro

Editor: Centro de Estudos Clássicos e Humanísticos

EDIÇÃO: 1a/2008

Concepção Gráfica: Rodolfo Lopes

Obra Realizada no Âmbito das actividades da UI\&D

Centro de Estudos Clássicos e Humanísticos

Universidade De CoImbra

FACUldAdE DE LeTRAS

TeL.: 239859981 | FAX: 239836733

3000-447 CoImbra

ISBN: 978-989-8281-04-3

ISBN Digital: 978-989-721-059-4

DOI: http://dx.doi.org/10.14195/978-989-721-059-4

Depósito Legal: 282470/08

Obra Publicada com o Apoio de:

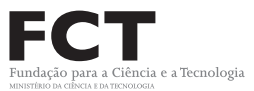

FUNDAÇÃO

CALOUŞTE

POCI/2010

GULBENKIAN 


\section{ÍNDICE}

$\begin{array}{ll}\text { PrefáCIO } & 7\end{array}$

$\begin{array}{lr}\text { BANQUETE } & 10\end{array}$

INTRODUÇÃOO 13

$\begin{array}{ll}\text { BANQUETE } & 30\end{array}$

Apologia de Sócrates $\quad 85$

$\begin{array}{ll}\text { INTRODUÇÃO } & 87\end{array}$

APOLOGIA DE SÓCRATES $\quad 99$

$\begin{array}{ll}\text { Bibliografia } & 117\end{array}$ 


\section{Prefácio}

Fazia parte do projecto da Comissão Organizadora do VIII Congresso da International Plutarch Society (2008) publicar, até à data da realização do Congresso, a tradução das obras que, sobre a temática, foram escritas em grego e em latim e de que ainda não exista uma versão fidedigna em Portugal. Entre esses textos encontramse o Banquete, a Apologia de Sócrates e os Memoráveis de Xenofonte, que nos dão de Sócrates uma visão diferente, mas complementar, daquela que nos é transmitida por Platão.

Daí termos solicitado a tradução das referidas obras de Xenofonte à Doutora Ana Elias Pinheiro que há anos as estuda, por terem sido matéria do seu Doutoramento. É precisamente a versão do Banquete e da Apologia de Sócrates do autor da Ciropedia que se inclui neste volume, a que se seguirá o dos Memoráveis.

A leitura destas obras talvez surpreenda um pouco quem está habituado ao retrato de Sócrates dos diálogos de Platão: grande filósofo, qualidades morais elevadas, amigo estimado e admirado, mas sem espírito prático e com frequência absorto nas suas reflexôes. Pelo contrário, o Sócrates que em Xenofonte encontramos é homem prático, virtuoso, útil e prestável aos amigos, que lhe pedem conselhos, mesmo sobre os seus negócios.

A versão portuguesa do Banquete e da Apologia de Sócrates de Xenofonte passa a pertencer-vos. Com a sua 
leitura, a personalidade de Sócrates surgir-vos-á a outra luz e haverá, de certeza, melhor compreensão do que representava para os amigos e para os Gregos em geral.

Coimbra, Setembro de 2008 José Ribeiro Ferreira 


\section{BANQUETE}




\section{INTRODUÇÃO}

É por demais conhecida a importância que este tipo de evento teve na cultura grega e o papel que desempenhou, durante muito tempo, numa espécie de 'educação ao longo da vida' com que a pólis ateniense, à falta de sistema de ensino superior, brindava os seus cidadãos. Vedado, em princípio, às mulheres (como tantos outros acontecimentos da vida ateniense), este tipo de reuniáo constava de um primeiro momento, o do 'jantar', e um segundo de 'bebida' (potos, de onde symposion, à letra, 'beber em conjunto'), espaço para discussóes de ordem vária e intervalos de lazer, com músicos ou dançarinas; prolongando-se pela noite fora, era normal que os convivas acabassem por beber demais (cf. Platáo, Banquete, 176a-d, 215d-e; Leis, 671c), degenerando a festa num clima de orgia, que, contudo, não parece verificar-se no relato de Xenofonte. Os temas escolhidos para discussão eram muitas vezes de ordem cultural, pelo que não admira, pois, que a literatura tenha, e com profusão, dedicado espaço à reprodução destes momentos. Destacam-se, entre os textos mais emblemáticos do género, conhecido como Sympotika, a obra homónima, e decerto contemporânea, de Platão, e, mais tarde, o Banquete dos Sete Sábios e No Banquete, de Plutarco, ou, ainda, o Banquete dos Eruditos de Ateneu ou o Banquete da autoria do Imperador romano Juliano ${ }^{1}$.

${ }^{1}$ Vide, sobre o assunto, W. Jaeger (1979), 670-677, e O. Murray (1994). 
Tal como acontece com a Apologia de Sócrates, também o Banquete retoma algumas referências ou situaçôes que se repetem em Memoráveis, a grande obra de referência escrita por Xenofonte a propósito do processo que condenara Sócrates à morte, em 399, podendo discutir-se se seria esta uma obra autónoma ou apenas um episódio mais da obra maior. Apesar das repetiçóes poderem abonar a favor da sua autonomia, o texto inicia, com um ả $\left.\lambda \lambda \alpha^{2}\right)$, mas dando ideia de uma continuação. Contudo, este é um recurso característico do estilo coloquial que Xenofonte pretendeu imprimir às suas obras em geral e ao qual recorreu de forma constante: usa $\delta$ ne no início do Económico e da Apologia e ả $\lambda \lambda$ á aqui no Banquete mas também na Constituição dos Lacedemónios.

Tal como aconteceu com outras obras de Xenofonte, a modernidade questionou também a autenticidade do Banquete. Contudo, tal como acontece também com as restantes, Antiguidade também não o fez; não me parece haver, pois, qualquer motivo para não o considerar de Xenofonte.

Se é certo que o estilo de composição de Xenofonte não é nunca muito organizado, essa desorganização, pelo menos aparente, atinge o seu clímax no Banquete. No entanto, e por paradoxal que possa parecer, é nesta estrutura caótica que reside o particular interesse desta obra e que a torna única no seu género e um dos melhores retratos do que verdadeiramente terão sido estes encontros. 


\section{CONTEXTO, CENÁRIO, DATA DRAMÁTICA E FIGURAS}

Este 'banquete' tem por cenário a casa do milionário ateniense Cálias ${ }^{2}$, no Pireu, e como pretexto a comemoração da vitória recente, numa competição de pancrácio, nas Grandes Panateneias de $422^{3}$, do jovem Autólico, filho de um Lícon, que poderia ser um dos acusadores de Sócrates ${ }^{4}$. Esta será, portanto, também a data dramática do encontro que conta com a participação, para além do anfitrião e do homenageado, de Critobulo, Hermógenes (meio-irmão de Cálias), Antístenes e Cármides; do pai de Autólico, Lícon, e de Nicérato, o filho de Nícias; e ainda de Sócrates e, pensam alguns (com base em 1.1), do próprio Xenofonte. Em todas estas personagens, nossas conhecidas no cenário ateniense, e que, também em Memoráveis, frequentam o círculo socrático, encontramos os traços que habi-

${ }^{2}$ Cálias aparece com alguma frequência neste papel de anfitrião: também em Platâo, Protágoras, e Êupolis, Parasitas (apud Ateneu, 5.218d). Vide, e.g., M. Dorati, «Platone ed Eupoli (Protagora 314c - 316a)», QUCC 50 (1995), 87-103.

${ }^{3}$ A data é confirmada por Êupolis que, numa comédia representada em 421 (apud Ateneu, 5.216d), satiriza esta mesma vitória, dizendo-a recente.

${ }^{4}$ Julga-se, habitualmente, embora sem certeza (Brisson, 2001: 74, n. 16), que possa corresponder ao Lícon acusador de Sócrates, referido por Platão, na Apologia, 23e, e do qual pouco se sabe, para além de que seria um orador relativamente afamado em Atenas. Em Vespas 1310, Aristófanes satiriza a mulher de um Lícon, que não sabemos se será o mesmo. A corresponder este Lícon ao acusador de que fala Platáo, os seus motivos poderiam estar relacionados com esta ligaçáo do filho a Cálias, que frequentava o círculo de Sócrates, ou com a suposta associaçáo do filósofo aos oligarcas de 401, que, segundo Lísias (Apologia, 15), teriam sido responsáveis pela morte de Autólico. 
tualmente as caracterizam: Cálias é pedante e afectado, Antístenes rude, Hermógenes circunspecto, Critobulo apaixonado. Duas outras figuras merecem ainda um particular destaque: o dono da companhia de dança (composta por uma flautista, uma dançarina e um acrobata e músico), referido como o Siracusano, e cujo trato grosseiro estabelece um contraponto ao que se espera da educação perfeita dos restantes convivas, e Filipo, um comediante, cuja figura apresenta largas semelhanças com o futuro parasita do teatro cómico.

Muito provavelmente, como acontecerá com os diálogos de Platão ou com muitos dos episódios de Memoráveis, não estaremos na presença de um acontecimento histórico; ele é, contudo, bastante verosímil. Somente a suposta presença de Xenofonte tem sido encarada como um elemento forjado; atendendo à data dramática do texto e aceitando que, provavelmente, o nosso Autor nascera nos primeiros anos do conflito do Peloponeso, não teria qualquer possibilidade de ter estado presente neste banquete 5 . Contudo, contra outras interpretaçóes, e pese embora o facto de a descrição apontar para um narrador presente, a verdade é que não leio que Xenofonte quisesse efectivamente dizer que presenciara 'este' banquete, em concreto: não se diz que ele acompanhava Sócrates aquando do encontro com Cálias, não participa em nenhuma das conversas duran-

5 Sobre a biografia de Xenofonte, vejam-se J.K. Anderson (1974) e H.R. Breitenbach (1967). Esta mesma situação ocorre nalguns dos diálogos reproduzidos em Memoráveis, e que Xenofonte parece também ter presenciado. 
te o jantar, e o que ele refere no início (1.1) aponta para o seu conhecimento ( $\gamma\llcorner\gamma \nu \omega ́ \sigma \kappa \omega$, conheço, não oî $\delta \alpha$, sei, como nalguns passos de Memoráveis, e.g., 1.2.18) de situaçóes como aquela, não para aquela em particular:

Pois, a mim não me parece que sejam dignas de lembrança apenas as acçôes sérias dos homens de bem mas também os seus momentos de diversão. E porque eu próprio os presenciei, quero agora transmitir o que conheço.

\section{ESTRUTURA DO TEXTO}

Este é, como já se disse, um texto aparentemente desorganizado e desestruturado, onde a cada capítulo irá corresponder uma situação diferente. Contudo, é precisamente esta simples justaposição de episódios que, melhor do que acontece com o texto homónimo de Platáo, construído de forma perfeita em torno de um assunto único ${ }^{6}$, permite a tal fidelidade de que falávamos ao retrato efectivo deste tipo de eventos. Correspondendo cada capítulo a um momento diferente do banquete podemos, contudo, tentar organizá-los deste modo: o texto inicia-se com um Prólogo, que ocupa o primeiro capítulo e apresenta a situação e os convivas. De seguida, o 'Banquete' propriamente dito poderá ser dividido em três partes, separadas por iguais momentos de pausa, a cargo da companhia de dança, em 2.1-2, 3.1 e 7 . A primeira parte corresponde sensivelmente ao segundo capítulo, onde, no meio de alguma desordem,

${ }^{6}$ Vide Platão. Banquete. Introdução, versão do grego e notas de M.T. Schiappa de Azevedo (Lisboa, 1991). 
será abordada a verdadeira educação do homem de bem (à letra kalos kagathos ${ }^{7}$ ); uma segunda parte, mais longa e aparentemente mais ordenada, abrange os capítulos 3-7, onde Sócrates propóe um jogo subordinado à questão, 'do que é que mais me orgulho?', ao qual responderão os vários convivas, inicialmente com uma resposta breve, depois com a respectiva explicação - 3.1-6, 4.1-6, Cálias: de ser capaz de tornar os homens melhores; 3.5-6, 4.6-10, Nicérato: de saber todos os versos de Homero; 3.7, 4.10-29, Critobulo: da sua própria beleza; 3.8, 4.3445, Antístenes: da sua riqueza (espiritual: ele que não possuía nem um óbulo); 3.9, 4.29-33, Cármides: da sua pobreza; 3.10, 4.56-64, Sócrates, numa curiosa comparação: dos seus talentos de alcoviteiro espiritual; 3.11, 4.50-51, Filipo: da sua capacidade de fazer rir; 3.1213: Lícon orgulha-se do filho e Autólico orgulha-se do pai; 3.14, 4.46-50: Hermógenes: dos amigos, os deuses; 4.52-55, o siracusano: do seu público. A cada um dos discursos dos vários convivas, o Autor apóe um remate sensivelmente igual e que serve, mesmo que de modo algo abrupto, para passar a palavra, ao interlocutor seguinte $^{8}$. Finalmente, Sócrates e Critobulo disputam um bizarro concurso de beleza (capítulos 5-6) que Critobu-

${ }^{7} \mathrm{O}$ kalos kagathos era, para os Atenienses dos fins da época arcaica, aquele que recebera uma educação completa e equilibrada, concretização de um ideal de excelência que pretendia aliar, numa só palavra, a beleza física e moral: a kalokagathia.

${ }^{8}$ Cf. 4.6: «e esta conversa acabou assim»; 4.10: «e esta conversa foi terminada mais ou menos assim»; 4.44: «foi isto o que ele disse»; 4.50: «este foi o discurso grave que fez»; 4.64: «e assim chegaram ao fim todas estas conversas». 
lo obviamente vence, mas de onde subjaz a ideia de que é mais importante a beleza espiritual. Uma terceira actuação dos bailarinos prefacia a terceira parte (capítulo 8), onde se discute o Amor e o fica expresso pensamento de Sócrates a este respeito: o verdadeiro amor não consiste na busca do amor carnal, mas, em amante e amado atingirem, em simultâneo, a kalokagathia, a 'perfeição'.

No final desta conversa, Autólico, que é ainda criança (cf. $1.2 ; 1.8$ ), abandonará a sessão na companhia do pai. Segue-se, então, uma representação final dos dançarinos, que, dada a pouca idade do homenageado, não poderia ter ocorrido na sua presença, uma espécie de Epílogo, que ocupa o capítulo 9, o último. Os dançarinos representam uma pantomima erótica dos amores de Dioniso e Ariadne, que conduzirá à saída dos convivas: os casados, excitados pelo espectáculo, correm ao encontro das suas mulheres; Sócrates e os outros darão um passeio pela cidade.

Feita esta divisão, afinal, a estrutura do texto ganha uma ordem clara: um tema preside, mesmo quando não explícito, às discussões - como atingir a perfeição, que distingue Sócrates, por exemplo, do dono da companhia de entretenimento; quanto às representaçôes dos dançarinos, elas funcionam, à maneira das intervençóes corais de uma peça de teatro, como intervalos, permitindo voltar à mesma discussão sob uma nova estratégia de abordagem. De resto, é particularmente interessante notar as semelhanças óbvias entre este texto e o teatro cómico, quer no modo com encena as situaçóes, quer pelo tom burlesco de algu- 
mas das suas figuras. A dramaticidade não era, de resto, um aspecto alheio também aos diálogos de Platão, e pese embora o facto de ter sido habitualmente justificada com um suposto interesse juvenil de Platáo pelo teatro ${ }^{9}$, a verdade é que a análise deste Banquete pode mostrar que o enfoque estava sobretudo nas semelhanças entre o teatro e o género dialógico em si mesmo ${ }^{10}$.

\section{Xenofonte e Sócrates}

Pese embora Diógenes Laércio, em 2.58, o ter incluído no rol dos filósofos, a verdade é que Xenofonte não escreveu tratados filosóficos, escreveu, sim, como outros coevos, textos que podemos incluir nestes Diálogos Socráticos que pretendiam defender e preservar o pensamento do mestre ateniense.

Os episódios que chegaram até nós da convivência de Xenofonte com Sócrates são poucos: o seu pró-

9 Sobre o assunto, vide D. Tarrant, «Plato as Dramatist», JHS 75 (1955), 82-89; L. Moulinier, "Dans quel sens et dans quelle mesure les Dialogues de Platon sont-ils des pièces de théâtre», Dioniso 41 (1967) 186-196; M.H. Rocha Pereira (2003), 486 e n. 3.

${ }^{10}$ Talvez tenha sido essa aproximação que permitiu também a associação estabelecida por Aristóteles entre os mimos e os Diálogos Socráticos. Na Poética (1447b11), Aristóteles refere estes Diálogos Socráticos como um género literário instituído (Já a arte que usa apenas simples palavras ou metros, combinando-os ou usando somente um tipo de metros, tem-se mantido sem designação, porque é possivel dar um mesmo nome aos mimos de Sófron ou de Xenarco e aos logoi socráticos) cuja origem atribuía a um certo Alexâmenos de Teos (Sobre os Poetas, frg. 3 Ross = Rose 272; cf. Ateneu, 505c; apud Guthrie, 1975: 320, n.16: Negaremos que os chamados mimos de Sófron, que nem sequer têm metro, sejam logoi e imitaçóes, tal como os diálogos de Alexâmenos de Teos que se escreviam antes dos diálogos socráticos?). 
prio testemunho, na Anábase 3.1.5, e o de Diógenes Laércio $(2.48)^{11}$.

Dizem que Sócrates se encontrou com ele num corredor estreito, estendeu o seu bastão para lhe impedir a passagem e perguntou-lhe onde podia encontrar coisas úteis; quando ele lhe respondeu, continuou, perguntando-lhe onde se faziam homens bons e virtuosos. Tendo ele ficado atrapalhado, Sócrates retorquiu: «Segue-me e ficarás a saber». E a partir dessa altura Xenofonte tornou-se seguidor de Sócrates. E foi o primeiro que transmitiu as suas conversas tal como elas tiveram lugar, e as publicou com o título de Recordaçôes. Foi também ele o primeiro dos filósofos a escrever sobre história.

Discute-se ainda se Xenofonte terá de facto pertencido aos círculos socráticos, uma vez que o único, de entre os reconhecidos como seguidores de Sócrates, que o cita é Ésquines, no diálogo Aspásia ${ }^{12}$. Mas, na verdade, parece que os Socráticos tiveram tendência para se ignorarem uns aos outros: Platão só de passagem refere Antístenes (Fédon, 59b), Ésquines (Apologia, 33e) ou Aristipo (Fédon, 59b) ${ }^{13}$ e ignora Xenofonte completamente;

${ }^{11}$ Um outro episódio referido por Estrabão (9.403) e repetido por Diógenes Laércio (2.22) terá confundido a figura de Xenofonte com a de Alcibíades; cf. Platão, Banquete, 220e; Plutarco, Alcibíades, 7 .

${ }^{12}$ Fr. 31 Dittmar = SSR VI A 70. O episódio reproduz um diálogo em que Aspásia dá conselhos a Xenofonte e à sua jovem mulher, situação, contudo, anacrónica, uma vez que Aspásia morre em 428, altura em que Xenofonte não teria mais do que dez anos (Kahn 1996).

${ }^{13}$ Vide Kahn, 1996: 5 e n. 9. As fontes antigas (vide Giannan- 
este, por sua vez, também só o refere uma única vez (em Memoráveis, 3.6.1), não o mencionando, por exemplo, quando, em Memoráveis 1.2.48, enumera os mais importantes seguidores de Sócrates: Críton, Querefonte, Querécrates, Hermógenes, Símias, Cebes e Fedondas; desta lista não consta Platão, mas, na verdade, também não constam Antístenes, nem Ésquines, nem Aristipo ${ }^{14}$. Provavelmente, diz Dorion (2000, xxiv), a ausência de referências, por parte de Platão, poderá ter significado não que Xenofonte não convivera com Sócrates, mas que Platão não o considerava um socrático; não podemos esquecer também que a única «lista», chamemoslhe assim, de socráticos em Platão é a do Fédon (59b) e dela, efectivamente, não podia constar Xenofonte, porque simplesmente, nessa época, não estava em Atenas. Embora pudesse ter havido entre alguns dos discípulos do mestre ateniense momentos de proximidade, como se pode inferir do episódio do Fédon, muito provavelmente eles terão sido circunstanciais e as suas diferentes opçóes filosóficas e pessoais, além das diferenças etárias, poderão ter sido motivo para a inexistência de uma convivência efectiva entre eles.

Também Breitenbach (1967: 1770) desvaloriza este facto, não achando improvável que Xenofonte te-

toni, 2001 292) dão conta de boas relaçôes entre Ésquines e Aristipo mas não entre Ésquines e Platão, ou entre Ésquines e Antístenes, nem entre Antístenes e Aristipo, ou entre Antístenes e Platão, e o próprio Aristipo teria feito eco de acusaçôes contra Ésquines de plágio às obras de outros socráticos.

14 Que não consta sequer da lista de Panécio em Diógenes Laércio, 2.64, 2.85. 
nha conhecido Sócrates tão bem como Platão: uma relação estabelecida talvez entre os anos de 409-401 teria dado a Xenofonte o tempo suficiente para ter sido influenciado pelo mestre. E na realidade, Xenofonte é até bem mais incisivo que Platão ao afirmar que frequentou o círculo socrático. Platão só uma vez (Apologia, 34a) se apresenta como espectador dos seus diálogos (embora faça questão de afirmar quando não está presente) e também nunca faz, como Xenofonte, apreciaçóes sobre o pensamento socrático nem emite opiniôes sobre Sócrates (Bruell, 1994, vii).

A Antiguidade, de resto, nunca questionou o relacionamento entre Sócrates e o escritor ${ }^{15}$ e, segundo Diógenes Laércio (2.64), Panécio incluíra os diálogos de Xenofonte na lista dos Diálogos Socráticos considerados 'dignos de crédito'.

Além do mais, como precisa Breitenbach (1967: 1772-1773), os Diálogos Socráticos devem ser vistos apenas como uma tradição socrática que não pode ser confundida com historiografia. É que, apesar de Sócrates ter sido uma figura histórica, o seu desempenho como filósofo ou professor não preenchia os requisitos necessários para ser considerado material historiográfico (factos e figuras pertencentes a um contexto político e/ou militar), ao invés do que sucedeu, por exemplo, com a sua actuaçáo como prítane durante processo das Arginusas e que Xenofonte refere nas Helénicas (1.6.287.35). Ter presente este pressuposto poderá evitar des-

${ }^{15}$ Vide Dorion 2000: xxvii, nn. 1 e 2; S. Pomeroy 1994: 21. 
necessárias especulaçôes sobre a historicidade dos textos socráticos de Xenofonte e da sua relação com o filósofo.

O próprio Xenofonte, de resto, assume, na sua obra, que a importância do seu testemunho se baseia no seu conhecimento ${ }^{16}$ : o seu retrato de Sócrates é mais correcto que o de outros porque ele conheceu Sócrates, como diz em 4.8.11., ao encerrar as sua recordaçóes: «sendo ele, de facto, tal como o descrevi». Mesmo reconhecendo-lhe a parcialidade que resulta do excesso de zelo que imprime à sua defesa de Sócrates não teremos talvez razão para duvidar da sua afirmação; só uma relação forte, mesmo que fugaz com o filósofo poderia, de resto, ter dado origem a tal empenho na sua reabilitação.

\section{O BANQUETE E OS MEMORÁVEIS}

Ao contrário do Banquete de Platão, que é um texto sério, este de Xenofonte é, assumidamente, um texto burlesco. E digo assumidamente porque o próprio Xenofonte faz questão de precisar no início (1.1) que vai lembrar momentos em que Sócrates e os que frequentavam a sua companhia se dedicavam a 'criancices', porque lhe parece que esses também são «momentos dignos de lembrança», ou seja, 'memoráveis'.

${ }^{16}$ A tendência para desvalorizar esta informação tem vindo, de facto, a esbater-se. Vide G. Giannantoni, SSR 4, 209-222 (apud Viano 2001: 99 e n.7), que coteja todas as passagens de Xenofonte que a crítica considerava como inautênticas e imputáveis a Antístenes e que são vistas agora como fruto, apenas, de temas comuns aos escritos socráticos em geral. 
Apesar de a intervenção de Sócrates neste diálogo ser muito menor do que nos de Platão ou mesmo do que em Memoráveis, um ponto em comum começaremos, então, por encontrar entre as duas obras: a intenção. É verdade que aqui esta é deduzida e que, ao contrário do que faz em Memoráveis, Xenofonte não diz que está a escrever em defesa de Sócrates, mas dos homens de bem, na sua generalidade; Sócrates é, contudo, um deles e os outros aqueles que com ele conviveram. De facto, como se de uma 'recordação' mais se tratasse, o nosso texto serviria bem a provar, como tantos dos episódios de Memoráveis, que Sócrates nunca corrompera os jovens: bem pelo contrário, só tem bons conselhos a dar aos que estão presentes na celebração, Autólico, o homenageado, e Critobulo, que encontraremos várias vezes, não só como interlocutor em Memoráveis, mas também na primeira parte de Económico (1.1-6.12). No caso de Autólico é, até, o próprio pai que o aconselha a ouvir Sócrates e as suas citaçóes dos poetas antigos, no caso, em 2.4, os versos célebres de Teógnis, que o filósofo cita também em Platão (Ménon, 95d) e que o próprio Xenofonte usa na sua argumentação, em Memoráveis, 1.2.20 $20^{17}$ :

${ }^{17} \mathrm{O}$ que é curioso é que se um qualquer acusador tivesse querido, poderia ter visto também nestes versos a mesma matéria para acusação que parece ter encontrado Polícrates nos versos de Hesíodo e de Homero referidos, respectivamente, em Memoráveis 1.2.56 e 1.2.59. Dado o contexto cronológico e político em que se terá movido Teógnis, este 'bom' dos seus versos teria, certamente, na sua origem, muito mais de social e aristocrático do que de moral. 
Enquanto dos bons aprenderás o que é bom, se, pelo [contrário, te misturares aos maus, perderás até o entendimento que tens.

Assim, se é verdade que os textos socráticos de Xenofonte podem certamente garantir a sua autonomia em relaçáo uns aos outros, não é menos verdade, contudo, que, no seu conjunto, eles constituem um todo fruto de uma mesma intenção, quase obsessiva, do seu Autor: assegurar que Sócrates morrera, injustamente condenado.

Ana Elias Pinheiro 


\section{BANQUETE}


Pois ${ }^{1}$, a mim, não me parece que sejam menos dig1 nas de lembrança as acções sérias dos homens de bem ${ }^{2}$ do que os seus momentos de irreflexão. E porque eu próprio os presenciei, quero agora transmitir o que sei.

Aconteceu por altura das corridas de cavalos das 2 Grandes Panateneias. Cálias, o filho de Hiponico, apaixonado por Autólico, um miúdo que tinha ganho no pancrácio, tinha-o levado a assistir à prova.

No final da corrida, Cálias dirigia-se com Autólico e o pai dele em direcçáo à sua casa do Pireu e com eles seguia também Nicérato. Ao ver Sócrates na companhia de Critobulo, Hermógenes, Antístenes e Cármides, ordenou a um dos criados que acompanhara Autólico e os seus, e aproximou-se de Sócrates e dos que o acompanhavam, dizendo:

— Em boa hora vos encontro! Vou dar um jantar em honra de Autólico e do pai e acho que seria muito mais brilhante se o meu saláo se visse ornamentado com homens com um espírito tão refinado quanto o vosso em vez de generais, comandantes de cavalaria e outros ambiciosos.

${ }^{1}$ No original $\alpha \lambda \lambda \lambda^{\prime}$. Esta partícula não é habitualmente usada para dar início a um texto (vide Denniston, The Greek Particles, 21 e 172) mas tal não terá de significar, contudo, que o texto pudesse ter alguma parte inicial perdida; cf. supra p. 14.

${ }^{2}$ Em grego, kalôn kagathôn andrôn, à letra, dos homens belos e bons; cf. supra p. 18. Na versão da expressão e dos seus cognatos, tentei, sempre que possível, manter o termo pelo qual a sua tradução se fixou em português: perfeição. Noutros casos, como este, pareceu-me que o significado se coadunava bem com a nossa expressão 'homem de bem'. 
Sócrates respondeu-lhe:

- Passas o teu tempo a desprezar-nos porque tu pagaste bom dinheiro a Protágoras para adquirires sabedoria e a Górgias, a Pródico e a muitos outros ${ }^{3}$ e olhas para nós como se fossemos uma espécie de autodidactas em matéria de filosofia.

- Até agora - replicou Cálias - tenho disfarçado na vossa frente a minha capacidade para desenvolver muitos e sábios discursos, mas, agora, no caso de querem acompanhar-me, hei-de mostrar-vos a que 7 ponto mereço a vossa atençáo.

De início, Sócrates e os seus, como era natural, agradeceram o convite sem se comprometerem; mas quando ficou claro que ele ia ficar muito aborrecido, caso não fossem, lá aceitaram. E assim, apareceram mais tarde, uns depois dos treinos e das massagens, outros depois de um banho.

Autólico estava sentado ${ }^{4}$ junto ao pai e os outros, naturalmente, estenderam-se nos leitos.

Quem quer que presenciasse a cena perceberia logo que a beleza é por natureza um predicado régio, especialmente se acompanhada de modéstia e discrição,

9 como era o caso de Autólico. De facto, tal como uma luz que surge no meio da noite atrai todos os olhares, assim também a beleza de Autólico fazia que todos virassem para ele os olhos, pois em nenhum dos que o olhava o

${ }^{3}$ A Protágoras, Pródico e Hípias vimo-los em casa de Cálias, no episódio recriado por Platão, no seu diálogo Protágoras.

${ }^{4}$ Por ser jovem ainda; nos jantares, enquanto os homens se reclinavam em leitos, as mulheres e as crianças ficavam sentadas. 
espírito deixava de ficar emocionado na sua presença: io uns emudeciam e outros tentavam, a todo custo, conterse. É certo que todos os que parecem estar possuídos por um deus são dignos de contemplação; mas enquanto os que são possuídos por outros deuses tendem a ter um olhar terrífico, uma voz assustadora e gestos violentos, os que estão inspirados pelo casto Amor têm os olhos cheios de ternura, uma voz doce e gestos mais nobres. Assim se comportava, Cálias, por causa desse Amor, o que o tornava muito mais interessante aos olhos dos que também estavam iniciados nesse mesmo culto.

Os convivas iam jantando em silêncio, como se I I assim tivesse sido determinado por algo superior. Eis senão quando bateu à porta Filipo, o comediante, pedindo a quem lha abriu que o anunciasse a ele e à razão que o trouxera. Dizia que vinha preparado com tudo o necessário, mas à custa dos outros, e acrescentava que trazia o moço muito contrafeito porque náo traziam nada e estava de estômago vazio.

Cálias, ouvindo tais palavras, exclamou:

- Na verdade, meus amigos, é uma vergonha negar-lhe nem que seja um tecto. Deixem-no entrar! E, ao tempo que falava, olhou para Autólico, para ver como reagira ele à brincadeira.

Filipo, de pé no meio do jantar, dirigiu-se aos convivas:

— Todos vocês sabem que sou um comediante. E estou aqui muito bem disposto porque acho que é muito mais engraçado vir jantar sem convite do que tendo sido convidado. 
- Pois, então, arranja um lugar — respondeulhe Cálias - , porque, como vês, os convidados estão muito sérios, mas pode ser que lhes apeteça rir.

E enquanto o jantar prosseguia, Filipo tratou logo de dizer qualquer coisa com piada, para dar cumprimento à razão pela qual costumavam convidá-lo para os banquetes.

Contudo, não obteve qualquer riso, o que o deixou visivelmente contristado. Pouco depois, quis dizer uma nova piada. Mas ninguém se riu dele pelo que deixou o jantar a meio, enrolou-se no manto e deixou-se

I5 estar deitado.

Cálias, então, perguntou-lhe:

- Que tens, Filipo? Dói-te alguma coisa?

Ele gemeu e respondeu:

- Dói, por Zeus, Cálias e muito! Porque, desde que o riso abandonou a humanidade, o meu negócio foi-se. Antes, era essa a razão pela qual me convidavam para jantar, para que os convivas se divertissem, rindo graças a mim. Mas agora, para que me hão-de convidar? Só que, para mim, tornar-me sério não seria menos difícil do que tornar-me imortal, e não ninguém vai querer convidar-me, para que eu retribua o convite, porque todos sabem que não é costume haver jantares em minha casa.

Enquanto falava, assoou-se e, pela sua voz, percebia-se claramente que estava a chorar. Todos tentaram, então, consolá-lo, dizendo-lhe que haviam de rir noutra ocasião e que iam continuar a convidá-lo para jantar e Critobulo até deu umas gargalhadas por causa dos 
seus lamentos. Então, ele, sentindo este riso, destapou o rosto, exortou o seu espírito à coragem para o combate que ainda tinha que travar à mesa e lá continuou o seu jantar.

Quando já tinham retirado as mesas, feito as libaçôes e entoado o péan ${ }^{5}$; apareceu-lhes para a festa um sujeito de Siracusa acompanhado por uma boa flautista, uma bailarina espantosa a fazer acrobacias e um rapaz muito bonito e muito bom a tocar cítara e a dançar. $\mathrm{O}$ Siracusano ganhava rios de dinheiro, com as suas actuaçóes. Depois de a flautista ter tocado a sua flauta e o rapaz a cítara, e de parecer que ambos tinham agradado bastante, Sócrates disse:

- Por Zeus, Cálias, trataste-nos mesmo bem. Não só nos serviste um magnífico jantar, como também nos proporcionaste o que há de mais agradável à vista e ao ouvido.

Cálias respondeu:

- E se nos trouxessem perfume para que nos deliciássemos também com um bom odor?

— Nem pensar — respondeu Sócrates — pois tal como certa roupa fica bem numa mulher e outra num homem, do mesmo modo há perfumes que convêm ao homem e outros à mulher. Nenhum homem, por exemplo, se iria perfumar por causa de outro homem; e às mulheres, sobretudo as recém-casadas, como a do nosso Nicérato e a do Critobulo, que falta lhes faz o perfume? Cheiram a elas mesmas! Já o cheiro do azeite, quando é

${ }^{5}$ Canto coral em honra dos deuses; era entoado entre o jantar e o symposion propriamente dito. 
4 usado nos ginásios, é mais agradável do que é o perfume para as mulheres, e quando falta também se sente mais. Além do mais, quando perfumados, tanto faz escravo como homem livre, cheiram todos à mesma coisa. Pelo contrário, os odores que exalam das fadigas dos homens livres exigem uma maior e mais longa dedicação para se tornarem agradáveis e dignos da sua condição.

Disse, então, Lícon:

- Pois, mas isso está bem para os novos; agora nós, que já não vamos aos ginásios, havemos de cheirar a quê?

— À perfeição ${ }^{6}$, por Zeus! — respondeu Sócrates.

- E onde arranjas tu um perfume desses?

- Nas perfumarias, não, claro.

- Onde entáo?

- Como disse Teógnis ${ }^{7}$ :

Enquanto dos bons aprenderás o que é bom, se, pelo [contrário, te misturares aos maus, perderás até o entendimento que tens.

Lícon respondeu, então:

— Estás a ouvir, meu filho?

- Claro que te ouve, por Zeus - interrompeu Sócrates - , e tira o partido que deve. Por exemplo, quando queria obter a vitória no pancrácio, depois de

${ }^{6}$ Cf. supra n.2.

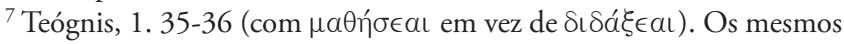
versos são citados por Sócrates em Platão, Ménon, 95 d. 
ter investigado contigo <quem seria melhor mestre para tal, foi ter com...; pois, quando se quiser tornar virtuoso, primeiro há-de analisá-lo contigo ${ }^{8}>$ e, depois, frequentará a companhia daquele que lhe parecer mais capaz para lhe ensinar a virtude.

Então, vários dos presentes se pronunciaram, perguntando um deles:

- E onde vai encontrar ele um tal professor?

Um respondeu que essa matéria nem sequer se poderia ensinar, enquanto outro defendia que se as outras matérias se podiam aprender também esta se podia.

Sócrates interrompeu-os:

- Como é um tema discutível, vamos deixá-lo para outra altura e vamos continuar agora o que nos tínhamos proposto. É que estou ali a ver a bailarina de pé e alguém que lhe traz uns arcos.

Nesse mesmo momento, a outra rapariga que acompanhava a dançarina começou a tocar, enquanto junto dela alguém lhe ia passando os arcos, ao todo doze. Ela apanhava-os, e logo os lançava ao ar e os fazia girar, calculando a altura a que devia atirá-los para depois os apanhar com ritmo.

Sócrates observou, então:

- Entre muitos outros exemplos que poderia dar, meus amigos, o que está esta rapariga a fazer prova que a natureza feminina náo é inferior à do homem em nada, excepto na falta de força e robustez. De modo que, se algum de vocês tem mulher,

${ }^{8} \mathrm{O}$ texto apresenta neste passo uma lacuna cujo sentido, contudo, pelo contexto da conversa, náo parece difícil de reconstituir. 
não deve hesitar em ensinar-lhe o que quiser que ela saiba? .

Antístenes retorquiu:

- Como é que, então, tu, sabendo uma coisa dessas não educas a tua Xantipa ${ }^{10}$, e aguentas a mais insuportável das mulheres que existem, e acho até das que algum dia tenham existido ou venham a existir.

- Sabes, é que eu tenho-me apercebido que os que querem chegar a bons cavaleiros não procuram os cavalos mais dóceis, mas os mais impetuosos; acreditam que se conseguirem domar estes, lidarão facilmente com todos os outros cavalos. Ora, eu, que quero conviver e conversar com pessoas, casei com ela, porque estou certo de que, se conseguir aguentá-la a ela, facilmente conseguirei conviver com qualquer pessoa.

Uma tal resposta não parecia destoar do tema que se estava a tratar.

A seguir trouxeram um arco que estava cercado de pontas de espada. A dançarina atirava-se para dentro dele dando voltas e tornava a sair, dando voltas também, por cima delas. Os que estavam a assistir receavam que se ferisse, mas ela conseguia fazê-lo

${ }^{9}$ É o que faz Iscómaco no Económico; mas a observação lembra, sobretudo, o célebre comentário do filósofo na República de Platão - uma cidade que não educa as mulheres é apenas meia cidade - e denuncia, decerto, a sua simpatia pelas práticas espartanas.

${ }^{10} \mathrm{O}$ mau génio da mulher de Sócrates tornou-se proverbial (cf. Platão, Fédon). Também em Memoráveis (2.2.10), mesmo sem a referir pelo nome, Xenofonte apresenta Sócrates em diálogo com o filho mais velho Lâmprocles, que se queixa precisamente do feitio intolerável da mãe. A resposta que lhe dá o pai é condizente com esta do Banquete: se não podes suportar semelhante mãe, não podes suportar nada de bom. 
com determinação e sem qualquer hesitação.

Sócrates então dirigiu-se a Antístenes, dizendo-lhe:

- Não me parece que aqueles que assistem a um espectáculo destes possam continuar a discutir se a coragem pode ser ensinada, quando até esta rapariga, sendo mulher, passa com tal destemor pelo meio das espadas.

Antístenes respondeu-lhe:

- Ora, assim sendo, não seria melhor que o nosso Siracusano exibisse a sua dançarina em frente à cidade, I 4 anunciando que, se os Atenienses estiverem dispostos a pagar-lhe, os tornará a todos igualmente destemidos frente às lanças inimigas?

- Sim, por Zeus — exclamou Filipo —, e eu desfrutaria vendo Pisandro, o demagogo, aprendendo a rodar no meio das espadas; ele que, agora, não consegue nem olhar para as lanças, nem está disposto a sair de campanha com o seu exército ${ }^{11}$.

A seguir começou a dançar o rapaz, e Sócrates disse:

- Já viram como este bonito rapaz parece mais bonito ainda, enquanto dança, do que quando está parado? Respondeu Cármides:

— Parece-me que estás a elogiar quem o ensinou a dançar.

- Sim, por Zeus - concordou Sócrates - até I6 porque reparei num outro aspecto: enquanto dança, parte alguma do seu corpo está parada, movimentando, ao mesmo tempo, o pescoço, as pernas e os braços, já que é assim que deve dançar aquele que pretender um corpo

${ }^{11}$ Figura altamente ridicularizado pelos cómicos atenienses pela sua cobardia. Platáo cómico compôs um Pisandro (Plutarco, Antifonte, 15). 
em boas condiçóes físicas. Até eu bem que gostaria de ter aprendido contigo, Siracusano, estes passos de dança.

— E de que te serviriam eles? — perguntou o outro.

- Pois, para dançar, por Zeus.

Todos riram ao ouvir a resposta. Sócrates, então, perguntou com ar bastante sério:

— Estão a rir de mim? Só porque quero fazer exercício para ter mais saúde ou ter mais prazer a comer ou a dormir, ou apenas porque me apetece fazer exercício, não como os corredores de fundo, cujas pernas engordam enquanto os ombros emagrecem, nem como os pugilistas que desenvolvem os ombros mas têm as pernas fracas, mas trabalhando todo o corpo de modo equilibrado? Ou riem-se porque náo precisarei de proI8 curar um companheiro de exercícios, nem terei de me estar a despir porque já estou velho e bastar-me-á um quarto com a medida de sete camas ${ }^{12}$, tal como agora chegou a este rapaz esta sala para se pôr a suar, e porque, durante o Inverno, terei de fazer exercícios debaixo de tecto e, quando o calor for muito, à sombra? Ou riem porque estou com a barriga grande e quero reduzi-la um pouco? Não sabem que ainda há pouco aqui o Cármides

I9 me apanhou a dançar?

— É verdade, por Zeus — respondeu Cármides - e a princípio fiquei perplexo, pensando que tivesses enlouquecido. Mas, quando te ouvi razóes semelhantes às que agora estás a enumerar, eu próprio, quando

${ }^{12} \mathrm{O}$ uso deste tipo de medidas aproximativas é comum entre os Gregos. 
cheguei a casa, só não me pus a dançar também, porque nunca aprendi; só sei dar umas voltitas com os braços.

- Mas, por Zeus — disse Filipo —, é por isso 20 que as tuas pernas pesam tanto como os teus ombros; se pesasses, diante dos fiscais da ágora, a parte de cima e a parte debaixo do teu corpo, como se fossem páes, náo te aplicariam qualquer multa.

Disse-lhe, então, Cálias:

-Ó Sócrates, quando fores aprender a dançar, tens de me chamar, para que seja o teu par e aprenda contigo.

- Nesse caso - disse Filipo - alguém que me acompanhe à flauta para que eu também possa dançar.

Levantou-se e começou a imitar os passos do rapaz e da rapariga. E tal como inicialmente tinham elogiado os gestos que faziam o rapaz parecer mais belo, no caso dele, cada movimento do seu corpo parecia ainda mais grotesco do que o habitual. E tal como a rapariga ao dobrar-se para trás imitava os arcos, ele fazia o mesmo agachando-se para a frente. E, finalmente, como tinham elogiado o rapaz porque a sua dança exercitava todo o corpo, ordenou à flautista que tocasse mais depressa e desatou a sacudir ao mesmo tempo o corpo todo, pernas, braços e cabeça. Mas, quando se cansou, deixou-se cair no leito e disse:

- Esta é a prova, meus amigos, que as minhas danças são também um bom exercício. Mas fiquei cheio de sede. $\mathrm{O}$ moço que me traga uma taça das grandes.

— Pois, por Zeus — pediu Cálias —, também para nós, que também estamos cheios de sede de tanto nos rirmos de ti. 


\section{Disse Sócrates, então:}

— Também a mim, meus amigos, me parece que é uma boa ideia que bebamos; na verdade, o vinho adormece as penas das almas dos homens, como faz a mandrágora com as pessoas, mas também desperta as alegrias como o azeite faz com o lume. Contudo, parece-me que ao corpo humano acontece o mesmo que acontece às

25 plantas na terra; essas, quando a divindade as rega em excesso, não conseguem erguer-se, nem se deixam penetrar pelas brisas, mas, quando bebem só o que querem, crescem muito direitas, florescem e dão fruto. Passa-se o mesmo connosco, se emborcarmos uma enorme quantidade de bebidas, rapidamente nos falharão os corpos e as mentes e não poderemos mais nem respirar, quanto 26 mais falar. Pelo contrário, se os criados nos forem brindando aos poucos com pequenas copas, para usar eu também palavras como as do Górgias ${ }^{13}$, não chegaremos a embebedarmo-nos dominados pelo vinho, mas persuadidos por ele havemos de chegar à maior das alegrias.

Assim parecia também aos outros. Filipo acrescentou que os escançóes deveriam imitar os bons corredores de carros, fazendo com que as taças corressem a volta mais depressa ${ }^{14}$. E eles assim fizeram.

A seguir, harmonizando a lira com a flauta, o rapaz começou a tocar e a cantar. Todos o aplaudiram.

Cármides disse, então:

- Parece-me, meus amigos, falando como fez o

13 Testemunhos como este mostram que o sofista era conhecido pelo seu estilo rebuscado já entre os coevos. Cf. Aristóteles, Retórica, 1406b.

${ }^{14}$ Os leitos dos comensais dispunham-se em círculo ou em ferradura. 
Sócrates a propósito do vinho, que também esta mistura da frescura dos jovens com a música adormece as penas e acorda o amor.

Sócrates tomou de novo a palavra:

- É claro, meus amigos, que eles parecem capazes de nos proporcionar prazer; mas, estou certo que nós nos achamos muito melhores que eles. Não vos parece, entáo, vergonhoso que nem sequer tentemos, estando juntos, sermos úteis ou agradáveis uns aos outros?

Muitos responderam:

- Mostra-nos tu, então, o que fazer e com que palavras teremos melhores resultados.

- Eu já ficaria muito satisfeito em cobrar a Cálias a promessa que me fez. Disse-me ele que, se aceitávamos vir ao jantar, nos mostraria a sua sabedoria.

— E mostro! Se todos vocês mostrarem também a vossa.

- Pois, nenhum de nós se opóe a dizer-te o que cada um pensa saber de mais importante.

- Pela minha parte - disse Cálias - devo 4 dizer-vos que aquilo de que me orgulho mais é de achar que sou capaz de tornar melhores os homens ${ }^{15}$.

Antístenes perguntou:

- E faze-lo ensinando-lhes algum ofício manual ou a perfeição ${ }^{16}$ ?

${ }^{15}$ Esse era também o objectivo do ensino do sofista Protágoras, no diálogo homónimo de Platão.

${ }^{16}$ No grego, ка入окả $\gamma a \theta i ́ a ;$ cf. supra n. 2 
- A perfeição, se entendermos que equivale à justiça ${ }^{17}$.

- Mas, claro, por Zeus - respondeu Antístenes —, isso é absolutamente indiscutível; porque a coragem e a sabedoria, muitas vezes, acabam por trazer o mal tanto aos amigos como à cidade, agora, a justiça nunca se mistura com a injustiça.

— Bem, - continuou Cálias ${ }^{18}$ — quando cada um de vocês tiver dito em que pensa ser útil, então eu próprio não terei qualquer problema em explicar-vos com que artes consigo esse resultado. Mas agora é a tua vez, Nicérato: diz-nos lá, qual o saber de que te orgulhas?

\section{Ele respondeu:}

- O meu pai, preocupado com que eu me tornasse um homem de bem, obrigou-me a aprender o Homero todo; de modo que agora seria capaz de recitar, 6 inteiras e de cor, a Ilíada e a Odisseia.

- Ora, e não sabes - interrompeu Antístenes - que todos os rapsodos conhecem esses versos?

- E como é que não haveria de saber, se os ouço quase todos os dias?

—E, por acaso, conheces gente mais estúpida do que os rapsodos? ${ }^{19}$

— Não, por Zeus, — disse Nicérato — acho que não.

${ }^{17}$ No grego dikaiosyne.

${ }^{18} \mathrm{O}$ texto original não indica que é o emissor desta fala, mas pelo seu teor entende-se que tem de ser o anfitriáo.

${ }^{19}$ Xenofonte faz idêntico comentário, em Memoráveis (4.2.3-40), no célebre episódio que tem por protagonista o jovem Eutidemo. 
— De facto- interferiu Sócrates —, é evidente que eles não conhecem o sentido profundo desses versos. Agora, tu pagaste bom dinheiro a Estesímbroto, a Anaximandro e a muitos outros, pelo que não desconheces nenhum dos seus valiosos ensinamentos. Então, e tu, Critobulo, de que te orgulhas mais?

- Da minha beleza.

— E podes mostrar-nos - espantou-se Sócrates - como é que a tua beleza nos pode tornar melhores?

- Claro! Caso contrário, pareceria um inútil, 8 não é verdade?

- E tu, Antístenes, de que te orgulhas mais?

— Da minha riqueza — respondeu ele.

Então, Hermógenes, perguntou-lhe se possuía muito dinheiro, ao que ele assegurou que não tinha nem um óbulo.

— Tens, então, muitas terras?

- Talvez a suficiente para o Autólico se empoeirar com ela.

- Vamos ter de ouvir a ti também. Então e tu,

Cármides: de que te orgulhas tu?

- Pois, eu sinto-me orgulhoso da minha pobreza.

- Por Zeus, - exclamou Sócrates - essa é de facto a situação mais agradável: não provoca invejas, não provoca disputas, guarda-se sem vigilância, e a falta de cuidado ainda a torna mais forte.

— Então e tu, Sócrates, — perguntou Cálias — Io de que te orgulhas tu?

Ele levantou a cabeça com uma expressão solene e respondeu: 
- De ser um alcoviteiro.

Riram-se todos da resposta e ele continuou:

- Vocês riem-se, mas eu sei que ganharia bom dinheiro, se quisesse praticar o ofício.

- E tu — disse Lícon a Filipo — é óbvio que te orgulhas de nos fazer rir.

- E acho que com mais justiça do que o actor Calípides, todo inchado porque consegue fazer chorar uma plateia inteira ${ }^{20}$.

— Então e tu, Lícon, — perguntou Antístenes não nos vais tu também dizer de que te orgulhas?

— Pois não sabem todos que deste meu filho?

— Bem, e ele, é óbvio, que da sua vitória - acrescentou alguém.

Autólico corou e disse:

— Não, por Zeus, eu não!

Estavam todos encantados por lhe ouvirem a voz e olharam para ele, enquanto alguém perguntou:

- E então de quê, Autólico?

- Do meu pai — respondeu que do pai e ao mesmo tempo inclinou-se para ele.

Cálias vendo-o, disse:

- Sabes, Lícon, que és o mais rico dos homens?

— Por Zeus, de facto, não sei!

— Mas, não vês que não aceitarias os tesouros do Grande Rei em troca do teu filho?

- Sou obrigado a concordar; realmente, parece que sou o mais rico dos homens.

${ }^{20}$ Célebre actor trágico de finais do século V (Aristóteles, Poética, 1461b35, 1462a9; Plutarco, Agesilao, 21, e Alcibiades, 32). 
— E tu, Hermógenes — perguntou Nicérato —, de que te orgulhas tu?

- Da virtude e do poder dos meus amigos, que, sendo o que são, se preocupam comigo.

Nessa altura, todos olharam para ele e muitos lhe perguntaram se não queria dizer quem eles eram. Ele respondeu que não teria inconveniente.

A seguir, foi a vez de Sócrates intervir:

- Resta-nos, então, a cada um demonstrar o que apresentou como motivo de orgulho.

- Peço-vos que me ouçam a mim, em primeiro lugar - pediu Cálias - . O tempo que demoro a ouvirvos questionarem-se sobre o que é justiça é o tempo que eu demoro a tornar justos os homens.

- E como consegues tu tal proeza, meu amigo? - perguntou Sócrates.

— Por Zeus! Dando-lhes dinheiro.

Antístenes, indignado, perguntou-lhe em tom bem inquisidor:

- E parece-te, Cálias, que os homens trazem a 2 justiça nas almas ou nos bolsos?

- Nas almas.

- Ah! Mas é passando-lhes dinheiro para o bolso que lhes tornas as almas mais justas?

- Claro!

- Mas, como?

- Porque, tendo com que comprar o que necessitam, não vão querer correr riscos cometendo delitos.

- E costumam devolver-te o que recebem?

- Claro que não, por Zeus, claro que não! 
- E agradecem-te, ao menos, o tal dinheiro?

— Não, de maneira nenhuma. Alguns até me detestam mais do que antes de o receberem.

- Que coisa espantosa! - exclamou Antístenes, fixando-o, com o mesmo ar inquisidor - Consegues que sejam justos com outros mas não contigo.

- E o que é que isso tem de espantoso? - perguntou Cálias - Também vês muitos carpinteiros e construtores que fazem casas para os outros, mas que não conseguem fazê-las para si mesmos e vivem em casas alugadas. Como vês, meu sabichão ${ }^{21}$, também tens de sofrer as minhas inquiriçôes.

— E tens mesmo, por Zeus — disse Sócrates Porque também dos adivinhos se diz que anunciam o futuro dos outros mas não são capazes de prever o próprio.

E a discussão acabou por aqui.

Depois foi a vez de Nicérato:

- Ouçam-me, por favor, no que hão-de ser melhores se seguirem os meus ensinamentos. Sabem, claro, que Homero, o mais hábil dos poetas, versou quase todos os temas humanos. Se algum de vocês quiser ser administrador, orador, general ou igualar-se a Aquiles, a Ájax, a Nestor ou a Ulisses, é só passar mais tempo comigo. É que eu sou perito em todas essas matérias.

- E conheces também a arte de ser rei? -

21 Em grego, 'sofista'. De Antístenes sabemos que pertencia ao círculo socrático mas que efectivamente partilhava dos interesses e práticas de ensino dos Sofistas (com Crátilo e Pródico coincide, por exemplo, no interesse pela linguagem). O termo, contudo, é utilizado aqui num tom claramente depreciativo e irónico. 
perguntou Antístenes — Porque Homero louvou Agamémnon por ser, ao mesmo tempo, um bom rei e um bom guerreiro ${ }^{22}$.

- Mas, claro, por Zeus, e também sei que quando se conduz um carro é preciso dar a volta contornado o marco ${ }^{23}$ e que:

inclinando-se o condutor no cimo do seu carro bem polido ligeiramente para a esquerda, e ao cavalo da direita gritar-lhe e espicaçá-lo enquanto afrouxa com as mãos as rédeas

E ainda sei outra coisa que poderão experimentar de imediato: há um passo onde Homero fala de «cebolas para acompanhar a bebida» ${ }^{24}$. Se alguém nos trouxer agora uma cebola, vão ver rapidamente como ela é útil: bebe-se com muito mais gosto!

Cármides interrompeu-o:

- Meus amigos, aqui o Nicérato quer voltar para casa a cheirar a cebola para que a mulher tenha a certeza que ninguém pensou sequer em beijá-lo.

— Sim, por Zeus — ripostou Sócrates —, mas assim arriscamo-nos a que fiquem com mais uma ideia ridícula a nosso respeito: a cebola parece ser, de facto,

${ }^{22}$ Ilíada, 3.179.

${ }^{23}$ Adaptaçáo dos versos 335-337 do canto 23 da Ilíada, em que Nestor ensina ao filho, Antíloco, como ganhar uma corrida de cavalos. Esta corrida fazia parte dos célebres jogos fúnebres em honra de Pátroclo, onde pela primeira vez nos é descrita uma série de provas que viriam a integrar as competiçóes imortalizadas sob a designação de Jogos Olímpicos.

${ }^{24}$ Ilíada, 9.630: estamos na tenda de Nestor. A cebola era um alimento desprezado pelas elites atenienses, o que mostra a que ponto chegava a obsessáo de Nicérato pelas obras de Homero. 
um bom acompanhamento, e não só dá mais gosto à comida mas também à bebida. Ora, se nos pomos a comêlas, agora depois de jantar, vão dizer que viemos a casa

9 de Cálias para nos empanturrarmos.

- Mas de modo nenhum, Sócrates - respondeu ele - , porque comer cebola convém precisamente a quem vai combater, é a mesma coisa que fazem os que alimentam com alhos os galos antes de os atiçarem para o combate. Agora, nós, parece que queremos mais beijar do que a lutar.

E a discussão ficou mais ou menos assim.

Critobulo disse, então:

- É a minha vez agora de vos dizer porque é que estou orgulhoso da minha beleza.

- Diz lá - pediram os outros.

— Pois bem, se eu não for belo, como eu acho que sou, entáo vocês com justiça deveriam ser castigados por me enganarem. Porque ninguém vos obriga, mas vocês estáo sempre a dizer-me que eu sou belo. E eu acredito!

I I Porque vos tenho por homens de bem ${ }^{25}$. Mas, se, de facto, sou belo e acontece convosco o mesmo que me acontece a mim diante de quem é belo, juro-vos, pelos deuses, que não trocaria a minha beleza pelo império do Grande Rei. Porque a mim dá-me mais prazer olhar para Clínias ${ }^{26}$ do que para todas as belezas do mundo. Poderia ficar cego para tudo resto desde que pudesse I2 ver apenas o Clínias. Até aborreço a noite e o sono por-

${ }^{25}$ Cf. supra n. 2.

${ }^{26}$ Este amor obsessivo de Critobulo por Clínias é criticado por Sócrates, de forma bastante irónica, em Xenofonte, Memoráveis, 1.3.8-10. 
que não o vejo e sinto-me grato ao dia e ao sol porque, de novo, me revelam Clínias. Também há outra coisa de que nos devemos orgulhar, nós que somos belos: o homem forte tem de obter os seus bens com esforço, o corajoso correndo riscos, o sábio falando. Agora, o belo, pelo contrário, pode conseguir qualquer coisa sem esforço. Eu, por exemplo, mesmo conhecendo o prazer das riquezas, sentiria maior prazer em dar a Clínias tudo o que tenho do que em receber de outra pessoa igual valor, e com gosto trocaria a liberdade pela escravatura, se Clínias quisesse ser meu dono. Assim, ser-me-ia mais fácil trabalhar do que estar sem fazer nada e preferiria arriscar-me por ele do que viver isento de perigos. Por isso, Cálias, se tu te orgulhas de tornar mais justos os outros homens, eu ainda me orgulho mais, e com maior razão do que tu, de os conduzir a toda a classe de virtude, porque com o nosso alento, nós que somos belos, tornamos os nossos amados mais desprendidos dos bens materiais, mais amantes de esforço e mais ávidos de glória nos perigos, e ainda mais modestos e comedidos, já que até coram mais do que o necessário. É uma loucura não escolherem os belos para generais. Eu, por exemplo, pelo Clínias, até atravessaria o fogo e estou certo que vocês fariam o mesmo por mim. Por isso, Sócrates, não questiones mais que a beleza seja útil aos homens. Também náo se deve desacreditar a beleza dizendo que murcha rapidamente: aquele que é belo em criança, é-o em jovem, em adulto ou em velho. A prova é que se escolhem os mais belos dos anciáos para carregar os ramos de Atenas, porque se reconhece que há beleza 
I8 em qualquer idade. E se de boa vontade se consegue das pessoas o que cada um deseja, então, estou certo de que eu, agora, sem dizer uma única palavra, convenceria com mais facilidade este rapaz e esta rapariga a beijarem-me do que tu, Sócrates, mesmo que fizesses uso de toda a tua eloquência.

— E como? Estás a vangloriar-te de seres mais belo do que eu?

- Mas, claro, por Zeus, - exclamou Critobulo - a menos que fosse o mais feio de todos os Silenos que aparecem nos dramas satíricos.

Sócrates, de facto, parecia-se com eles ${ }^{27}$.

- Certo, lembra-me, entáo, de fazermos um concurso sobre a nossa beleza, quando acabarmos esta conversa. E os juízes serão não o filho de Príamo, Alexandre, mas estes que estão aqui e que, achas tu, estão mortos por te beijar ${ }^{28}$.

— E o Clínias, Sócrates, não te submeterias ao seu juízo?

- Mas será que tu não consegues deixar de pensar no Clínias?

- Achas que vou pensar menos nele, por não dizer o seu nome? Não sabes que trago na alma uma imagem dele tão nítida que, se tivesse de o esculpir ou o pintar, não o faria de modo menos fiel do que se estivesse a olhar para ele.

27 Os Silenos estavam, tal como as Bacantes, associados ao culto dionisíaco e como elas integravam os cortejos teatrais. Também em Platão, Banquete, 15b-c, é referida a semelhança de Sócrates com um sileno.

${ }^{28} \mathrm{Na}$ referência a Alexandre, ou Páris, filho de Príamo, o leitor coevo reconheceria claramente a alusão ao mais célebre de todos os julgamentos de sempre: o julgamento das três deusas, causa remota da Guerra de Tróia. 
Sócrates comentou, então:

— Pois, se tens tão nítida a imagem dele, para que estás sempre a incomodar-me, arrastando-me para onde o possas ver?

- Ora, Sócrates, porque vê-lo faz-me feliz, enquanto que a imagem em vez de prazer produz saudade.

Disse, então, Hermógenes:

- Ó Sócrates, não me parece que te fique muito bem não te preocupares mais com Critobulo, que está tão afectado pela sua paixão amorosa.

- E achas que ele está assim desde que se dá comigo?

— E desde quando, então?

- Não vês que ainda agora lhe está descer um buço desde as orelhas, enquanto a barba de Clínias já sobe para trás? ${ }^{29} \mathrm{~A}$ verdade é que quando frequentavam a mesma escola, apaixonou-se perdidamente por ele. Quando o pai $^{30}$ percebeu, mandou-mo para ver se eu 24 podia fazer algo de útil.

E olhem que está muitíssimo melhor! Antes era como aqueles que contemplam as Górgonas; olhava-o petrificado, sem conseguir afastar-se dele. Agora, até já o vi a piscar o olho. Embora, pelos deuses, meus amigos, dizem por aí que até já beijou o Clínias; ora, não há nada de mais perigoso para atiçar o amor, porque

${ }^{29}$ Frase estranha que Studniczka (apud Zaragoza, 327, n.56) esclarece comparando a imagem descrita com a das figuras de Aquiles e Pátroclo na Taça de Sósias de Berlim.

${ }^{30}$ Críton, amigo de Sócrates. 
um beijo é insaciável e leva a esperanças voluptuosas. [E o facto, de entre todos os nossos comportamentos, só a união dos lábios ter a mesma designação ${ }^{31}$ do amor das almas, faz com que o beijo tenha uma importância muito maior].

É por isso que eu digo que aquele que quiser ser casto não deve beijar rapazinhos ${ }^{32}$.

Cármides interveio então:

- Na verdade, Sócrates, fazes um grande estardalhaço na frente dos teus amigos para os afastar dos rapazes belos, mas eu próprio, por Apolo, já te vi a ti, um dia, na escola, quando andavam à procura de uma coisa no mesmo livro, com a tua cabeça apoiada na cabeça dele e o teu ombro nu encostado ao ombro nu de Critobulo?

- Pois exactamente — respondeu Sócrates foi por isso que, como se tivesse sido mordido por um animal selvagem, eu fiquei com o ombro a doer-me para cima de cinco dias e parecia que me tinham mordido o coração. Mas, agora, — continuou — ó Critobulo, voute proibir aqui na frente destas testemunhas todas que me toques até que tenhas tanta barba no queixo como tens cabelo na cabeça.

E era assim que as brincadeiras se misturavam com as conversas sérias.

Então, disse Cálias:

31 Em grego, o verbo philein é usado tanto para amar como para beijar.

32 O Sócrates de Xenofonte diz o mesmo, também a propósito de Critobulo, em Memoráveis 1.3.9-13. 
— É a tua vez, Cármides, de explicar porque te sentes orgulhos da tua pobreza ${ }^{33}$.

— Pois bem — respondeu Cármides — , não está toda a gente de acordo em que é melhor ter coragem do que medo, que é melhor ser livre do que ser escravo, que é melhor ser objecto de cuidados do que ter de dispensá-los a outros, ter a confiança da pátria em vez da sua desconfiança? Pois bem, eu, aqui na cidade, quando 30 era rico, tinha medo que alguém me assaltasse a casa, me roubasse os meus bens e me fizesse mal; depois, tinha de adular os sicofantas, pois sabia que mais depressa me podiam fazer mal eles a mim do que eu a eles. Além disso, a cidade estava sempre a exigir-me mais gastos e não me permitia viajar nem circular livremente. Agora, pelo contrário, como já não tenho bens no estrangeiro, como já não tiro qualquer proveito de colheitas na minha propriedade e se vendeu boa parte do meu património, desfruto dormindo o que me apetece, tornei-me o homem de confiança da cidade, ninguém me ameaça, posso até ameaçar outros, e sou livre de sair da cidade ou de ficar por aqui. À minha passagem, os ricos levantam-se e cedem-me o passo na rua. Pareço um rei ${ }^{34}$, enquanto antes era claramente um escravo: era eu quem pagava tributo ao povo, enquanto agora é a cidade que me paga tributo a mim e me sustenta. Mais, quando era rico, condenavam-me por me dar com Sócrates, mas desde que sou pobre já ninguém se incomoda comigo. Quando tinha muito, estava sempre a perdê-lo, ou por causa

33 A sua pobreza também é referida em Memoráveis, 3.7.1.

${ }^{34}$ Em grego, tiranos. 
da cidade ou por azar; agora, já não perco nada porque náo tenho nada e ainda tenho sempre a esperança de ganhar alguma coisa.

— Ora - perguntou Cálias —, não tens vontade de voltar a ser rico e, se tiveres um bom sonho, fazes um sacrifício para o afastar?

— Não, por Zeus, não faço nada disso; aguento todos os riscos destemidamente, se tiver esperança de conseguir alguma coisa nalguma parte.

- Então e tu, Antístenes, — continuou Sócrates - como é que, não tendo grandes bens, te orgulhas de ser rico?

- Porque eu acredito, meus amigos, que as pessoas não têm a riqueza e a pobreza dentro de casa, mas

35 nas suas almas. De facto, vejo muitas pessoas comuns que, mesmo tendo grandes riquezas, se consideram táo pobres que afrontam todo o tipo de fadigas e de riscos para terem ainda mais e sei até de irmãos que tendo herdado partes iguais, um tem o suficiente, às vezes até lhe sobra, e ao outro falta-lhe tudo. Também sei de alguns reis $^{35}$ que têm uma tal sede de riquezas que cometem 36 crimes mais atrozes do que os pobres mais necessitados, porque a necessidade leva muitos a roubar, a assaltar, a vender homens livres como escravos; e há reis que destroem famílias inteiras, que chacinam populaçóes e que até reduzem cidades inteiras à escravatura para conse-

37 guirem riquezas. Pois bem, faz-me muita pena este tipo de indivíduos por causa da doença que têm: é como

${ }^{35}$ Em grego, túpavvol. 
uma pessoa que por mais que tenha e que coma, esteja sempre com fome. Eu tenho tantos bens que nem consigo vê-los! Mas ainda tenho que chegue para comer até já não ter fome, ou beber até já não ter sede e para me vestir de maneira a que quando saio não tenho mais frio do que o nosso Cálias, que é riquíssimo. E, quando estou em casa, os muros parecem-me túnicas cálidas e os telhados mantos grossos e a cama que tenho é tão boa que até me custa levantar-me. E quando o corpo me pede amor, chega-me táo bem o que tenho, que as mulheres de que me aproximo me enchem de carícias, porque nenhum outro quereria aproximar-se delas. E todos estes prazeres me parecem tão agradáveis que náo desejaria encontrar mais prazer ao praticar cada um deles, mas menos; acho até que alguns me são mais doces do que convém. Mas aquilo que possuo de mais valor na minha riqueza é que se alguém me tirasse o que tenho agora, não vejo nenhum trabalho, por pobre que fosse, que não me proporcionasse o suficiente para viver. Porque, até quando quero comprar alguma coisa, não compro no mercado o que há-de mais luxuoso, que é também o mais caro, e vou antes buscá-lo ao armazém da minha alma. O meu prazer é muito maior quando espero que as coisas me façam falta para as procurar do que quando consumo qualquer coisa cara, como acontece agora, que tenho aqui este vinho de Tassos, mas bebo-o sem ter sede. Além disso, é lógico que sejam muito mais justos os que preferem a simplicidade à abundância de bens, porque os que se conformam com o que têm anseiam menos pelo alheio. Vale a pena considerar como este 
tipo de riqueza torna os homens mais liberais, e o exemplo é aqui o Sócrates, a quem devo a minha riqueza, que não fazia cálculos, nem media o que me dava, e proporcionava-me tudo quanto eu pudesse levar. E eu agora também não o escondo de ninguém, mostro a todos os meus amigos a minha abundância e partilho com 44 quem o desejar a riqueza da minha alma. Além do mais, o mais precioso dos bens, o ócio, esse tenho-o sempre, e por essa razão posso ver os espectáculos que merecem mais ser vistos, ouvir o que de melhor se pode ouvir, e, o que ainda me é mais caro, passar o tempo livre de que disponho junto a Sócrates. Ele também não procura mais os que levam mais caro, mas antes convive sobretudo com aqueles de quem gosta.

Foram estes os seus argumentos.

Cálias disse, então:

- Por Hera! ${ }^{136}$ Se invejo a tua riqueza é também porque nem recebes ordens da cidade, como se fosses um escravo, nem as outras pessoas se incomodam por não lhes emprestares dinheiro.

— Não, por Zeus, não o invejes — disse Nicérato - , porque eu vou pedir-lhe emprestado não precisar de nada, eu que aprendi com Homero a contar

sete suportes novos, dez talentos de ouro, vinte caldeiros reluzentes, doze cavalos, ${ }^{37}$

${ }^{36}$ Este é um juramento tipicamente feminino, mas costuma aparecer com frequência na boca de Sócrates; cf. Fédon, 230b. Vide, sobre o assunto, W.M. Calder, "The oath by Hera in Plato", in Mélanges Édouard Delebecque (Aix-em-Provence, 1983), 35-42.

${ }^{37}$ Iliada, 11.122 e 264. 
pesando e contando porque não paro de aspirar a ter a maior riqueza possível. Se calhar é por isso que alguns me acham demasiado ambicioso.

Começaram todos a rir, convencidos de que ele estava a falar a sério.

Ouve alguém que disse então:

- É a tua vez agora, Hermógenes, de dizer quem são os teus amigos e demonstrar que têm grande influência e que se preocupam contigo, para deixares claro porque é que te orgulhas deles?

— Ora bem, é evidente que Helenos e bárbaros acreditam que os deuses sabem tudo, tanto o presente, como no que há-de vir. Por exemplo, todas as cidades e todos os povos, através da adivinhação, perguntam aos deuses o que é que devem que fazer e o que é que não devem fazer. Também é certo que acreditamos que eles são capazes de nos fazerem bem e de nos fazerem mal. A verdade é que todos pedem aos deuses que afastem deles calamidades e lhes concedam benefícios. Pois bem, estes deuses, que sabem tudo e são omnipotentes, são de tal modo meus amigos que na sua preocupação por mim nunca afastam de mim o seu olhar, nem de noite, nem de dia, onde quer que vá, nem em qualquer coisa que pretenda fazer. Pela sua capacidade de previsão também me indicam o que vai acontecer em cada situação, enviando-me mensageiros, vozes, sonhos e voos de pássaros, dizendo-me o que tenho de fazer e o que não devo fazer; quando lhes obedeço, não tenho qualquer motivo para me arrepender, mas ocasióes houve já em que, por não ter seguido as suas indicaçôes, fui castigado. 
A estas palavras respondeu Sócrates:

- Nada do que dizes me surpreende, mas ainda assim, deixa-me perguntar-te como os serves para que eles sejam tâo teus amigos.

— Por Zeus — respondeu Hermógenes —, é um serviço muito barato: louvo-os, o que não me traz qualquer despesa, ofereço-lhes uma parte do que me dáo a mim, falo bem deles sempre que posso e quando juro por eles nunca o faço em falso.

- Por Zeus! - disse Sócrates - Se com esse comportamento consegues a sua amizade é porque os deuses, acho eu, também prezam a perfeição.

Estas palavras foram proferidas assim, em tom sério.

Quando chegou a vez de Filipo, perguntaram-lhe o que via ele nas farsas, para se orgulhar delas:

- Ora, então não vale a pena, quando todos, sabendo que eu sou um comediante, quando acontece alguma coisa de bom, me chamam logo para participar, enquanto, quando lhes acontece alguma desgraça, fo5I gem de mim como do demónio, com medo de começarem a rir à gargalhada?

Disse-lhe, então, Nicérato:

- Por Zeus, tens boas razóes para estar orgulhoso. A mim, os meus amigos, quando lhes acontece algo de bom, afastam-me do caminho, mas, se acontece alguma desgraça, fazem tudo para procurar algum parentesco nas nossas genealogias e não me largam mais.

— Está certo — disse Cármides —; então e tu, Siracusano, de que te orgulhas tu? É óbvio que do teu rapaz? 
- Não, por Zeus, claro que não. Traz-me até 53 muitos cuidados, porque sinto que há muitos a tentar perdê-lo.

Sócrates, ao ouvi-lo, disse:

- Por Héracles! Que mal tão grande fez o teu rapaz para que o queiram matar?

— Não, o que eles querem não é matá-lo; querem deitar-se com ele!

- E tu achas que se isso acontecesse ia conduzilo à perdição?

- Sem dúvida nenhuma, por Zeus!

— Então, e tu não te deitas com ele?

- Claro, por Zeus, todas as noites e durante a noite inteira.

— Então, por Hera — exclamou Sócrates —, que grande sorte tens tu, que tens tão boa pele que és o único que náo estragas os que se deitam contigo. Devias estar orgulhoso pelo menos da tua pele.

— Pois não, por Zeus, não é disso que me orgulho.

- Então, do que é?

— Da insensatez dos homens, por Zeus; são eles que me sustentam, vindo ver os meus bonecos.

— Era por isso, então, — disse Filipo — que te ouvi recentemente a pedir aos deuses que, no sítio onde tu estivesses, trouxessem colheitas abundantes e uma grande falta de inteligência.

— Já está bem! — interrompeu Cálias — E ago- $\quad 56$ ra, Sócrates, podes dizer-nos porque te orgulhas dessa arte de má fama a que te referiste?

— Vejamos, em primeiro lugar, quais são as acti- 
vidades de um alcoviteiro. Não tenham dúvidas em responder a tudo quanto vos pergunte, para termos a certeza no que é que estamos de acordo. Parece-vos bem?

— Sem dúvida — responderam. E foram respondendo com o mesmo 'sem dúvida', a cada uma das questóes.

— Pois bem — continuou Sócrates — não vos parece que é próprio do bom alcoviteiro fazer com que a mulher ou o homem que prostitui sejam agradáveis a quem se relaciona com eles?

- Sem dúvida - responderam eles.

— E para agradar náo é preciso ter cuidado com os cabelos e com as roupas?

- Sem dúvida.

- E não sabemos também que o homem, como os mesmos olhos, pode olhar de modo amigável ou odioso?

- Sem dúvida.

— E uma mesma voz não pode ser discreta e descarada?

- Sem dúvida.

- E as conversas, não podem levar as pessoas tanto à inimizade como à amizade?

- Sem dúvida.

- Então, destas artes, não deveria um bom alcoviteiro ensinar aquelas que fossem as mais convenientes para se ser agradável?

- Sem dúvida!

- E quem será melhor, o que pode tornar agradável uma única pessoa ou várias?

Nesta questão, as respostas dividiram-se; uns di- 
ziam que «Obviamente o que o faz com muitos»; outros continuavam a responder "Sem dúvida».

Depois de ter conseguido que concordassem com 60 ele neste ponto, Sócrates continuou:

- E se alguém fosse capaz de tornar agradáveis todas as pessoas da cidade, não seria o alcoviteiro perfeito?

— Claramente, por Zeus! — responderam todos.

— E se alguém fosse capaz de o fazer com aqueles que mandam, não estaria com razão orgulhoso da sua arte e com razão pediria um bom salário?

Como estavam todos de acordo, prosseguiu:

— Na minha opiniáo, esse homem é aqui o nosso Antístenes.

— Eu, Sócrates? Estás-me a passar o lugar?Claro, por Zeus, porque vejo és bem melhor numa arte complementar.

- E qual é?

- O de intermediário.

Ele exclamou indignado:

- Ora essa, e porque achas tu que eu me dediquei a essa actividade, ó Sócrates?

- Porque te tornaste intermediário entre aqui o Cálias e o sábio Pródico, quando percebeste que este ansiava por sabedoria e o outro precisava de dinheiro. E sei que também o puseste em contacto com Hípias de Elide, com quem aprendeu a técnica da memorização, o que ainda o tornou mais apaixonadiço, porque agora não consegue esquecer quando vê uma coisa bela. 
Ainda há pouco, quando me fizeste o elogio do estrangeiro de Heracleia, fizeste-me desejá-lo e relacionar-me com ele. E só tenho a agradecer-te; parece-me, de facto, um homem de bem. E quanto a Ésquilo de Fliunte, elogiando-o na minha frente e a mim na dele, não nos deixaste de tal modo apaixonados, por causa das tuas palavras, que andávamos um atrás do outro como se fos-

64 semos cães de corrida? Vendo essa tua capacidade acho que és um bom intermediário. Porque o homem que é capaz de reconhecer os homens que lhe podem ser úteis e consegue fazer com que eles se desejem uns aos outros, acho que também seria capaz de fazer com que as cidades se tornassem aliadas ou concertar os casamentos certos, e que ter um homem desses como aliado seria de extrema importância tanto para as cidades como para os seus amigos. E tu ficas ofendido, como se ao dizer que és um bom intermediário, te estivesse a dizer uma coisa terrível.

— Não, por Zeus, agora já não; se, de facto, tenho uma tal capacidade vou ter a minha alma coberta de riquezas.

E assim ficou concluída esta ronda de intervenções.

Cálias disse, então:

— Então e tu, Critobulo, não vais enfrentar o Sócrates, no tal debate sobre a beleza?

— Não vai fazê-lo — disse Sócrates —, porque sabe que aqui o alcoviteiro tem boa fama diante dos juízes.

— Pois, pelo contrário, não me vou esquivar a 
isso; assim, que mostra-me lá, já que és tão sãbio, que és mais belo do que eu. Só é preciso que alguém aproxime uma lucerna.

— Muito bem! — respondeu Sócrates — Começo por te intimar diante da justiça. Tens de me responder.

- Podes perguntar.

— Achas que a beleza só é apanágio do homem 3 ou também está presente noutras coisas?

- A mim parece-me, por Zeus, que também existe num cavalo, num boi e até em coisas inanimadas. Sei que um escudo pode ser belo, e também uma espada e uma lança.

- E como é possível que estas coisas, que não 4 têm qualquer parecença, sejam todas elas belas?

- Ora, por Zeus, todas estas coisas são belas se forem produzidas em conformidade com as actividades para as quais as adquirimos ou naturalmente dotadas para fazer face às nossas necessidade, então são belas ${ }^{38}$. - respondeu Critobulo.

— Sabes então para que nos são úteis os olhos?

- Claro, para vermos.

— Então os meus olhos são mais belos do que os teus.

- Como assim?

- Porque os teus só vêem a direito, enquanto os meus, como são esbugalhados, também conseguem ver para os lados.

${ }^{38}$ O Sócrates de Xenofonte diz o mesmo no diálogo com Aristipo, em Memoráveis, 3.8.4-7. 
- Queres dizer que, de todos os animais, os caranguejos são os que têm os olhos mais belos?

- Exactamente, porque têm os olhos que melhor se adequam à sua natureza.

- Certo, então e que nariz é mais belo, o teu ou o meu?

- Acho que o meu, se é que os deuses nos deram o nariz para cheirar; porque as tuas narinas estão viradas para baixo, enquanto as minhas são arrebitadas e por isso captam os cheiros que vêm de todos os lados.

- E como é que um nariz achatado pode ser mais belo que um direito?

- Porque não atrapalha e deixa que os olhos vejam o quiserem, enquanto um nariz alto é como se erguesse uma muralha arrogante diante dos olhos.

- Quanto à boca, - disse Critobulo - já ganhaste. É que se foi feita para morder, podes morder muito mais do que eu; e, como tens os lábios grossos, não achas também que os teus beijos devem trazer mais felicidade do que os meus?

- Ouvindo o que dizes até parece que a minha boca é mais feia que a dos burros. Mas achas que o facto de as Náiades, sendo deusas, darem à luz os Silenos, muito mais parecidos comigo do que contigo, prova que eu sou mais belo do que tu?

Critobulo respondeu:

- Já nem sei que te diga; vamos lá a votos, para saber quanto antes qual é a minha pena ou a minha multa. Mas peço que votação seja secreta; não quero que a tua riqueza e a do Antístenes pesem contra mim. 
O rapaz e a rapariga votaram, então, de forma 9 secreta. Sócrates pediu para que alumiassem também Critobulo, para que os juízes não se enganassem e que o vencedor recebesse como prémio dos juízes, não fitas, mas beijos.

Quando se virou a urna e todos os votos eram a IO favor de Critobulo, Sócrates lamentou-se:

- Ai, o teu dinheiro, Critobulo, não se parece com o de Cálias porque o dele torna os homens mais justos e o teu, como acontece na maior parte das vezes, corrompe os juízes e os jurados.

Depois disto, uma parte dos assistentes animava Critobulo a receber os beijos que premiavam a sua vitória, enquanto outros tentavam convencer o dono dos moços e outros iam gracejando.

Como Hermógenes permanecesse calado, Sócrates chamou-o e perguntou-lhe:

— Sabes dizer-nos, ó Hermógenes, o que é ter mau beber?

— Se me com exactidão, não sei; mas posso dizer o que me parece ser.

- Então, diz lá, o que te parece?

- Acho que ter mau beber é tornar-se uma com- 2 panhia desagradável por causa do vinho.

- E não achas que, neste momento, nos estás a tornar a tua companhia desagradável por causa do teu silêncio.

- Enquanto vocês falam?

- Não, nos intervalos da conversa.

— Não achas que enquanto vocês falavam nin- 
guém podia meter no meio um pelo quanto mais uma palavra?

Sócrates respondeu:

— Ó Cálias, não podes vir aqui ajudar um homem que está posto entre a espada e a parede?

- Vamos a isso! Sempre que a flauta estiver a tocar, nós calamo-nos todos.

Hermógenes respondeu:

- Querem, então, que faça como o actor Nicóstrato, que recitava tetrâmetros ao som da flauta, que fale também eu ao som da flauta?

— Pelos deuses, Hermógenes — disse Sócrates —, faz isso. Acho que tal como o canto é mais agradável ao som da flauta, também as tuas palavras se tornariam mais doces ao som da música, especialmente se as acompanhares de gestos, ao compasso das palavras, como faz 5 a flautista.

Disse Cálias, então:

- Ora, assim sendo, quando o nosso Antístenes estivesse a interrogar um dos convidados, qual seria a música apropriada?

- Para quem estiver a ser interrogado acho que a melhor música seria o silvo — resmungou Antístenes.

Enquanto estavam com estas conversas, o Siracusano vendo que ninguém prestava atenção às suas exibiçóes, porque se entretinham uns aos outros, voltou-se para Sócrates, aborrecido:

—É a ti que chamam o pensador?

${ }^{39}$ Cf. Aristófanes, Nuvens. 
- Seria pior se me chamassem o que não pensa.

- Sim, mas diz-se que pensas sobre essas coisas lá de cima ${ }^{40}$.

- E sabes de algo que seja lá mais acima do que os deuses?

- Mas, por Zeus, não é com os deuses que dizem que tu te preocupas, e sim com coisas completamente inúteis.

- Mesmo assim, estar-me-ia a preocupar com os deuses, pois é lá de cima que nos ajudam com a chuva e é lá de cima que nos dão luz. E se o que eu digo é pouco interessante, tu também és culpado por me estares a desafiar.

- Deixa-te disso, e diz-me a quantos passos de 8 pulga estás de mim? Dizem que também te dedicas à geometria ${ }^{41}$ ?

Antístenes interveio, então:

- Ó Fipilo, tu que és o máximo a fazer essas comparaçôes, não achas que aqui o nosso amigo pode ser comparado a um insultuoso.

- Sim, e há por aí muitos outros como ele.

Sócrates interrompeu-o:

- Não te ponhas a fazer muitas comparaçóes, 9 não vás parecer tu também um inconveniente.

- Bem, se o comparasse aos que são mais belos e melhores ${ }^{42}$, estaria mais certo que me chamassem adulador do que inconveniente.

\footnotetext{
${ }^{40}$ Em grego, meteôroi.

${ }^{41}$ Cf. Aristófanes, Nuvens, 144.

${ }^{42}$ Em grego, kaloi kagathoi; cf. supra n. 2.
} 
— Pois agora mesmo estás a achá-lo inconveniente porque qualquer outro é melhor do que ele.

- Queres então que o compare aos que sáo piores que ele?

— Não, aos que são piores, também não.

- Que não o compare com ninguém?

- Exactamente. Não o compares com ninguém.

- Bem, mas se me calo não vou estar a pagar o preço que devo por este jantar.

— Será muito fácil — respondeu Sócrates —, basta que estejas calado, precisamente nas alturas em que não deves falar.

E ficaram por aqui este episódio de mau beber.

A seguir, uns propunham que se continuasse com as comparaçóes, outros que náo.

No meio do burburinho que se levantou, Sócrates tornou a intervir:

- Já que estamos todos com vontade de falar, porque não cantamos em coro? - e ele começou logo a cantar.

Quando acabaram, trouxeram à bailarina uma roda semelhante à dos oleiros em cima da qual ela havia de executar alguns malabarismos.

Sócrates disse, então:

— É provável, Siracusano, que, como dizias há pouco, eu seja um pensador; agora mesmo estou aqui a matutar o é que o teu rapaz e tua rapariga poderiam fazer para nos dar um espectáculo de que gostássemos;

3 e tenho a certeza de que é isso mesmo que queres. Ora, parece-me que saltar entre espadas é uma exibição pe- 
rigosa que não se apropria ao banquete; ler e escrever em cima da roda, enquanto ela gira, pode ser um espectáculo admirável, mas náo estou a ver que prazer nos possa dar; e ver os corpos dobrados para imitar arcos também não é mais agradável do que vê-los parados. De facto, não é difícil encontrar uma coisa que nos surpreenda quando necessitamos dela; é até muito comum surpreender-nos com as coisas que estão ao nosso lado, como: por que é que a lâmpada dá luz só porque tem uma chama brilhante, mas o cobre que também é brilhante não dá luz, mas reflecte as imagens de outros objectos. Ou por que é que o azeite, apesar de líquido, aviva as chamas, enquanto a água, precisamente porque líquida, as apaga. Mas estas também são questóes que, neste momento, não combinam com o vinho. Agora, se eles dançassem ao som da flauta, imitando os gestos das Graças, das Horas ou das Ninfas, acho que o fariam com muito mais facilidade e que o banquete ficaria muito mais agradável.

O Siracusano respondeu:

— Por Zeus, tens razão, Sócrates; vou apresentarvos um espectáculo que vos trará grande prazer.

Quando o espectáculo acabou, o Siracusano foi aplaudido e Sócrates retomou o seu discurso:

- Meus amigos, será razoável que, tendo entre nós uma grande divindade, que partilha o tempo com os deuses eternos, embora de aspecto mais jovem, que domina todas as coisas com o seu poder e que se instala na alma do homem, o Amor, nos estejamos a esquecer dele, sobretudo quando todos nós fazemos parte do seu 
círculo? Eu acho que não houve momento algum em 2 que não tenha estado apaixonado por alguém; aqui o nosso Cármides, sei que teve muitos que o amaram e que ele próprio suspirou por alguns. Critobulo, que ainda agora é amado, já está a suspirar por outros. Também

3 Nicérato, pelo que ouvi dizer, está apaixonado pela mulher e é correspondido. Quanto a Hermógenes, qual de nós é que não sabe que é a perfeição o que o apaixona? Não estão a ver a sua fisionomia severa, o olhar sereno, a moderação das palavras, a doçura da voz, o feitio alegre? E, apesar de tratar como amigos os deuses mais veneráveis, não despreza os homens, pois não? E tu, Antístenes, és o único que não estás apaixonado por ninguém?

- Ora, pelos deuses, estou perdidamente apaixonado por ti!

Sócrates respondeu-lhe, entre brincalhão e vaidoso:

— Ah! Não te ponhas agora com isso, bem vês que estou ocupado com outro assunto.

Antístenes replicou:

- Vê-se bem, meu alcoviteiro de ti próprio, estás sempre a fazer-me a mesma coisa! Umas vezes não falas comigo porque a tua divindade ${ }^{43}$ não te deixa,

${ }^{43} \mathrm{O}$ célebre daimonion, pelo qual o filósofo se dizia inspirado (à letra, que lhe dava sinais, Memoráveis, 1.1.2). Esta ideia de um Sócrates inspirado por uma espécie de voz divina (Xenofonte, Apologia, 12), que alerta e inspira o filósofo, está presente também na obra de Platão, onde, embora Sócrates se apresente a si mesmo como uma pessoa razoável (Platão Críton, 46b; Eutifron, 6a), a este daimonion, que lhe dá indicaçôes sobretudo do que não deve fazer, se vêm juntar ainda certos sonhos premonitórios: no Criton 44a, prevê que Platão virá a ser um grande filósofo (cf. Paus. 1.30.3); no Fedro 279a-b, prevê a fama futura de Isócrates; no Fédon 118a, prevê a sua morte próxima. 
outras porque está ocupado com outro assunto.

— Pelos deuses, Antístenes — respondeu-lhe Só-

crates — só não me batas! De resto, eu suporto o teu feitio violento e hei-de continuar a suportá-lo amigavelmente. Mas vamos esquecer esse teu amor, porque não se dirige à minha alma mas apenas à minha beleza. E quanto a ti, Cálias, toda a cidade sabe que amas Au7 tólico e acho que o sabem até muitos estrangeiros. Isto porque os vossos pais são muito conhecidos e mesmo vocês os dois são figuras públicas. Eu sempre admirei a tua maneira de ser, mas agora ainda te admiro mais, por ver que estás apaixonado náo por um sujeito efeminado pela preguiça, nem amaneirado por uma vida mimada, mas alguém que mostrou a todos a sua força e resistência, a sua bravura e a sua contenção. Estar apaixonado por essas qualidades abona a favor da natureza do amante. Se só há uma Afrodite ou se são duas, a Celestial e a Vulgar, não sei. Até Zeus, que parece ser só um, tem vários nomes. $\mathrm{O}$ que sei, sim, é que cada uma delas tem altares separados, templos e rituais; mais livres e descontraídos, os da Vulgar; mais puros, os da Celestial. Será normal, então, supor-se que a Vulgar preside aos desejos do corpo e a Celestial aos da alma, aos da amizade e aos das boas acçóes. Parece-me, Cálias, que esse é o amor que te possui. Prova-me o facto de a pessoa que amas ser dotada de perfeição e porque vejo que fazes que o pai o

Em Xenofonte as referências ao daimonion repetem-se com frequência em Memoráveis e são mais indicativas do que impeditivas, aludindo em simultâneo a o que fazer e o que não fazer, e mais abrangentes, afectando não apenas Sócrates mas também os seus seguidores. 
acompanhe quando te encontras com ele. Porque um homem de bem náo tem nada a esconder do pai daquele que ama.

- Por Hera, Sócrates - interrompeu Hermógenes - é por isso que eu te admiro tanto; agora, ao mesmo tempo que está a ser amável com Cálias, estás também a ensinar-lhe como se deve comportar.

— Sim, por Zeus — respondeu Sócrates —, e, para que ainda possa desfrutar mais, tenciono mostrar-

I3 lhe que o amor da alma é superior ao do corpo. Todos sabemos que, sem amizade, nenhuma relação vale a pena. Pois bem, ao amor dos que admiram o carácter chamase habitualmente uma doce e livre imposição; pelo contrário, muitos dos que só desejam o corpo, censuram e detestam os gestos dos que amam. E mesmo que amem

I4 corpo e alma, a flor da juventude tem as estaçóes contadas e, quando murcha, a amizade forçosamente murcha com ela; a alma, pelo contrário, quanto mais o tempo

I5 avança, mais sábia e digna se torna. Além disso, a fruição da beleza física acaba por fartar, de modo que, tal como depois de comer demais, ficamos enfartados, forçosamente acaba por acontecer o mesmo com esses prazeres com rapazitos. Pelo contrário, a amizade da alma, como é pura, não traz fastio, mas também não compensa menos em prazer, como alguém poderia pensar. Com ela cumpre-se precisamente aquela oração ${ }^{44} \mathrm{com}$ a qual pedimos à deusa que nos conceda ser dignos das suas I6 obras, por palavras e acçóes. A admiração e a amizade

${ }^{44}$ Desconhecida? 
que manifesta pelo amado uma alma bela e livre, modesta e generosa, que se destaca entre as da mesma idade, sem deixar de ser afectuosa, não são sentimentos que precisem de explicaçôes. O que vou demonstrar, sim, é como é natural que um tal amante seja correspondido pelos seus amados. Em primeiro lugar, quem poderia odiar alguém que nos considere perfeitos? Alguém que sabemos que luta mais em prol do bem do amado que do seu próprio prazer? Alguém que lhe garante que a sua amizade não diminuiria mesmo que fizesse alguma coisa errada ou que se tornasse feio por causa de uma doença? Como é que aqueles que estão unidos por uma amizade is comum não hão-de ser felizes a olhar um para o outro, não hão-de de conversar com carinho, não hão-de confiar e receber confiança, não hão-de de cuidar um do outro, de se alegrar com os sucessos, de se afligir nos desaires, de desfrutar quando estão de saúde e de se encontrar com mais frequência ainda quando um deles está doente, de ter ainda maior cuidado quando estão longe do que quando estão perto? Estas coisas todas não fazem parte dos encantos do amor? Fazendo assim, passam a vida toda até à velhice amando a amizade e desfrutando dela. Pelo contrário, aquele a quem só preocupa o corpo, por que razão é que haveria de ser correspondido pelo mais novo? Por procurar a satisfação dos seus próprios desejos e deixar ao rapaz a pior das vergonhas? Ou por tentar afastar o amado dos outros, sobretudo dos familiares? E o facto de não se servir da força, mas da persuasão, ainda o torna mais odioso, porque aquele que é violento revela-se como ser perverso, enquanto aquele que 
convence corrompe a alma de quem se deixa convencer.

2I De facto, aquele que vende a sua beleza por dinheiro, porque é que há de ter mais afecto ao seu comprador do que alguém que vende qualquer produto no mercado? E como pode haver amor, quando se une quem é novo a quem não é, quem é belo a quem já não o é, quem está apaixonado a quem não está? Assim, o rapaz não participa, como uma mulher, dos requebros amorosos do homem, mas antes contempla abstémio um homem

22 embriagado pelo amor. Não é pois de estranhar que até ganhe aversão ao amante. E, quem pensar um pouco, descobrirá que não há desentendimentos entre aqueles que se amam pelas suas qualidades, enquanto em relaçóes sem pudor acontecem muitos crimes.

23 Agora vou explicar como é impróprio de um homem livre relacionar-se com quem prefere o amor do corpo ao da alma. Com efeito, aquele que ensina a falar e a actuar como convém, com razão deve receber louvores, como Quíron e Fénix receberam por causa de Aquiles. Pelo contrário, aquele que só pensa no corpo é natural que se veja tratado como um mendigo; anda sempre atrás de alguém, mendigando um beijo ou uma

24 carícia. Se a minha linguagem for excessivamente desavergonhada, não se espantem: é o vinho que me excita, mas também o Amor que convive sempre comigo e que me incita a falar com veemência contra o outro Amor

25 que é seu rival. Aquele que apenas se preocupa com a sua figura parece-me aquele que arrendou um terreno e que, por essa razão, náo se preocupa em aumentar o seu valor mas apenas em retirar dele a maior colheita 
possível. Pelo contrário, aquele que procura a amizade parece-se mais com aquele que é dono de um campo: investe em tudo quanto possa melhorar e aumentar o valor daquele que é objecto do seu afecto. Além disso, um rapaz que é amado e sabe que, com a sua beleza, dominará o seu amante, é lógico que não invista tanto; agora, aquele que sabe que, se não for um homem de bem, não conservará uma amizade, esse certamente dará muito mais atenção à virtude. Ora, o maior bem, para aquele que procura no rapaz que ama um bom amigo, é que forçosamente tem de exercitar a virtude, pois, com más acçóes, não tornará melhor o moço com quem convive e, com falta de vergonha e de domínio, não tornará o seu amado nem atinado nem decoroso.

Estou ansioso, Cálias, por te mostrar, com exem28 plos da mitologia, que não são apenas os homens, mas que também os deuses e os heróis dão mais importância ao amor espiritual do que ao comércio do corpo. Vê Zeus que, a todas as mortais a que se uniu, seduzido pela sua beleza física, deixou-as continuar mortais, enquanto tornava imortais aqueles cujas almas nobres admirou. É o caso de Hércales e também dos Dióscuros e, dizem, de outros. Digo eu, até, que, a Ganimedes, Zeus levou-o 30 consigo para o Olimpo, não por causa do seu corpo, mas da sua alma, como o próprio nome testemunha. Em Homero, de facto, encontramos a expressão «Exulta ao ouvi-lo ${ }^{45}$ ", que quer dizer 'Ouve-o com prazer'. E, noutro passo, lê-se "tendo no espírito pensamentos pru-

${ }^{45}$ Os sublinhados são meus. 
dentes ${ }^{46}{ }^{\prime}$, ou seja, 'conhecedor no seu espírito de sábios conselhos'. Ora, como é composto de ganytai, 'exulta', e de medea, 'pensamentos', o nome Ganimedes significará não 'aquele que exulta o corpo' e, sim, 'aquele que exulta o espírito', e essa é a razão pela qual o honraram

3 I os deuses. Além disso — não é, Nicérato? — Homero representa a Aquiles vingando Pátroclo de maneira gloriosa, não por ser seu favorito, mas por ser seu companheiro de armas. E Orestes e Pílades, tal como Teseu e Pirítoo, e muitos outros semi-deuses famosos, não são celebrados em muitos poemas por terem dormido juntos, mas porque unidos por uma admiração mútua levaram a cabo, em conjunto, grandes e belos feitos. E, se

32 falássemos de actos nobres dos nossos dias, não teríamos dificuldade em constatar que são praticados por aqueles que estão dispostos a enfrentar dificuldades e riscos por amor à glória e não por aqueles que preferem o prazer à fama. Pese embora Pausânias, o amante do poeta Ágaton, ter dito, em defesa dos intemperados, que um exército poderia ser muito mais poderoso se constituído por amantes e amados ${ }^{47}$. Dizia ele que, na sua opiniáo, estes

33 mais do que outros se envergonhariam de se abandonarem uns aos outros. Esta afirmação é espantosa, pois significaria que, aqueles que menos se preocupam com censuras e que menos vergonha têm, seriam os que mais se preocupariam por não cometer actos vergonhosos.

${ }^{46}$ Estas expressões, na verdade, não figuram no Homero que conhecemos.

${ }^{47}$ Ambos são personagem no Banquete de Platão, mas esta ideia é, aí, defendida por Fedro e não por Pausânias. 
Como prova dizia que essa era a opinião de Tebanos e 34 Elidenses, quando afirmavam que, apesar de se deitarem com os seus favoritos, faziam com que eles alinhassem a seu lado no combate. Este é um hábito que nada tem a ver com o nosso caso, pois entre eles é um hábito que está normalizado, enquanto nós temo-lo por imoral. Até me parece que ao colocá-los ao seu lado é porque não confiam que, sozinhos, aqueles que amam, sejam capazes de agir como homens valentes. Pelo contrário, os Lacedemónios ${ }^{48}$, que julgam que aquele que cede aos apetites do corpo não obtém nada nem de belo nem de bom, instruem de tal modo aqueles que amam na coragem que, até entre os estrangeiros e sem estar alinhados pela mesma cidade que os seus amantes, nunca os envergonham abandonando os seus camaradas; porque acreditam na Vergonha e não na Desonra ${ }^{49}$.

Julgo que estaríamos todos de acordo com o que 36 estou a dizer, se nos perguntássemos a qual dos dois tipos de amantes iríamos confiar os nossos bens, os nossos filhos ou o nosso reconhecimento. Acho que até aquele a quem agrada mais a beleza física do seu amado, confiaria melhor todas estas coisas àqueles que amassem a sua alma.

Quanto a ti, Cálias, acho que deves agradecer aos deuses que te tenham inspirado o amor por Autólico. É óbvio que aspira à glória, já que, para ser proclama-

48 Sócrates, que era assumidamente admirador do sistema espartano, está equivocado ou a querer equivocar-se propositadamente, para fazer vencer a sua teses. Cf. Xenofonte, Constituição dos Lacedemónios, 2.12, e Platão, Banquete 182a-b, para as diferenças de atitude face à pederastia por parte de Tebanos e Eleios e Espartanos e Atenienses.

${ }^{49}$ Em grego, Aidôs e Anaideia. 
do pelos juízes vencedor no pancrácio, suportou muitos

38 trabalhos e penas. E se julga que não só trará honra para ele e para o pai, mas também que, graças à sua valentia, fará o bem aos amigos e aumentará a grandeza da pátria, erguendo troféus ganhos ao inimigo, obtendo a admiração de todos e sendo ilustre, tanto entre Helenos como entre bárbaros, como não acreditar que terá também as maiores honras aquele que melhor o acompanhar em

39 tais empreendimentos? Assim, se lhe quiseres agradar, tens de rever quais os conhecimentos que tornaram possível que Temístocles libertasse a Hélade, tens de estudar o que sabia Péricles para ter sido considerado o melhor conselheiro da cidade, tens de ver como outrora as reflexôes de Sólon lhe permitiram promulgar as melhores leis para a cidade e tens também de te perguntar com que treinos podem os Lacedemónios ser considerados os melhores chefes militares. Tu és representante dos governos estrangeiros e é em tua casa que se hospedam os

40 mais importantes deles. Portanto, sabes que, em breve, a cidade se colocará nas tuas mãos, se assim o quiseres. Tens todas as qualidades requeridas: de famílias tradicionais ${ }^{50}$, sacerdote dos deuses que instituiu Erecteu, que com Íaco defrontou os Bárbaros, e agora, nas suas celebraçóes pareces ser um sacerdote mais imponente do que os teus antepassados, tens um porte digno de se ver na cidade e uma figura capaz de suportar esforços.

Se parecer que estou a falar com demasiada seriedade, para quem está a beber, não se espantem. Partilho

${ }^{50}$ Em grego, 'eupátridas'. 
sempre com a cidade da paixão por homens bons por natureza e que procuram a virtude com entusiasmo.

Enquanto os outros discutiam sobre o que tinha 42 acabado de se dizer, Autólico contemplava Cálias. E Cálias, olhando-o de soslaio, disse:

- Então, Sócrates, vais prostituir-me diante da cidade, para que me dedique aos assuntos públicos e nunca deixe de te agradar?

- Sim, por Zeus, - exclamou ele — com a

condição de que todos vejam que te preocupas com a virtude, não apenas em aparência, mas a sério. Porque as falsas aparências rapidamente as desmascara a experiência; pelo contrário, o verdadeiro valor, só se um deus não quiser, é que não torna maior o brilho da fama com cada uma das suas acçóes.

A conversa acabou assim. Autólico levantou-se, porque já se fazia tarde, para ir dar o seu passeio. Lícon, o pai, que se dispunha a sair com ele, virou-se para Sócrates e disse-lhe:

— Por Hera, Sócrates, pareces-me ser um homem de bem.

Assim que saíram, foi instalado na sala um cadei2 rão e entrou o Siracusano anunciando:

- Meus senhores, Ariadna vai entrar no quarto nupcial que partilha com Dioniso. Depois há de entrar Dioniso, embriagado depois de um banquete entre os deuses, aproximar-se-á dela e brincarão os dois.

Entrou então Ariadna, vestida de noiva, e sentou3 se no cadeirão. Ainda não chegara Dioniso, quando se ouviu da flauta um ritmo báquico. E assim puderam 
apreciar o trabalho do ensaiador; mal ouviu o som, Ariadna pôs-se a gesticular de modo que todos percebiam como estava feliz por ouvi-lo. Não saiu ao encontro do deus, nem se levantou, mas era notório que 4 mal podia esperar. Quando Dioniso a viu, correu para ela, dançando como faria o marido mais apaixonado, sentou-se-lhe no colo, abraçou-a e beijou-a. Ela parecia envergonhada mas correspondeu ao abraço, com amor.

Os convivas aplaudiam gritando «Outra vez, outra vez».

Dioniso levantou-se e ajudou Ariadna a levantarse e era extraordinário de ver os passos e as figuras dos amantes, beijando-se e abraçando-se. E vendo que Dioniso, verdadeiramente belo, e Ariadna, tấo encantadora, não fingiam os beijos que davam na boca, todos os espec-

6 tadores ficavam muito excitados. Pareceu-lhes ouvir Dioniso perguntar-lhe se o amava e ela fazendo juras tão apaixonadas que, não apenas Dioniso, mas todos os presentes seriam capazes de jurar que rapaz e rapariga se amavam efectivamente. Não pareciam actores ensaiados para esta pantomima mas duas pessoas a quem permitiram realizar 7 algo que há muito desejavam. No final, vendo os convivas que os dois ficavam abraçados e se retiravam, parecendo que iam dormir juntos, os solteiros juraram casar-se e os casados montaram os seus cavalos e galoparam rumo às suas mulheres, para receberem iguais prazeres. Sócrates e os outros que restavam saíram com Cálias para se juntarem a Lícon e ao filho, no seu passeio.

E com esta saída terminou o banquete. 
APOLOGIA DE SÓCRATES 


\section{INTRODUÇÃO}

\section{XeNofonte OU NÃo?}

O texto faz parte das obras apresentadas por Diógenes Laércio (2.57), na biografia do historiógrafo, que por sua vez se basearia numa lista anterior atribuída a Demétrio de Magnésia (séc. I d.C.), e não consta que a Antiguidade tenha posto em causa esta autoria, como o confirma também Ateneu (218e), que refere como fonte Heródico da Babilónia (séc. II a.C.?).

A dúvida instala-se nos finais do nosso século XVIII, com Valkenaër (Marchant 1921), seguido por outros, entre os que se contam Wilamowitz (1890: 581, apud Tovar 1957:14 e n.2; Ollier 1972:84): as suas suspeiçôes baseavam-se numa fraca qualidade atribuída à obra e nas muitas repetiçóes em relação aos Memoráveis, que conteriam já, por sua vez, elementos retirados do Fédon e da Apologia de Platão.

Mesmo em trabalhos mais recentes, Erbse (1967: 262), por exemplo, parece continuar a considerá-la espúria, diferenciando Xenofonte, autor dos Memoráveis, daquele a quem ele chama o autor da Apologia.

Contudo, não foi possível a nenhum dos especialistas que têm negado a autoria da obra encontrar-lhe um outro autor provável ou uma outra época de composição. Assim, parece que a efectiva semelhança de estilo, estrutura e vocabulário com outras obras de Xenofonte pode constituir uma boa razão para continuarmos a atribuir-lhe a autoria que a Antiguidade lhe conferiu (Ollier 1972: 89). 


\section{A Apologia e os MemoráveIS}

Não se me oferecem quaisquer dúvidas que este texto é composto numa íntima ligação ao texto mais longo que Xenofonte compôs em defesa de Sócrates $^{1}$, os Apomnemoneumata, conhecidos com o nome de $M e m o r a ́ v e i s^{2}$, porquanto segue muito de perto os elementos aí enunciados por um Xenofonte, autornarrador, que faz suas as palavras que aqui coloca na boca de Sócrates. A acusação é apresentada de modo idêntico e autor segue também a mesma metodologia para rebater essas acusações (cf. Memoráveis, 1.1-2 com Apologia, 10-21).

É comum, em termos de cronologia relativa, fazer com que a Apologia preceda os Memoráveis, considerando-a uma espécie de rascunho, depois retomado e completado, em particular no Livro 4 (8.4), e em geral no todo da obra.

Contudo, julgo que o argumento habitualmente utilizado para defender esta tese é tão válido como o seu contrário. Se julgamos a Apologia anterior pelo facto de não se referir à existência dos Memoráveis, como podemos justificar que também aí Xenofonte não faça qualquer referência ao opúsculo de defesa, se anteriormente publicado? Mantenho assim a dúvida de que o

${ }^{1}$ A relação destes textos de Xenofonte com o processo de Sócrates e com a chamada literatura foi já por mim abordada no volume de edição de Memoráveis ().

2 Apomnemoneumata, 'o que merece ser lembrado', é o título listado por Diógenes Laércio, em 2.52; depois Aulo Gélio (14.3) intitula-os Commentarii, e a partir da edição de Johann Lenklau (Frankfurt, 1596) fixamse sob o título de Memorabilia ([Coisas] Memoráveis). 
texto possa ser considerado não uma versão preliminar, mas uma adenda, onde o autor retomaria um aspecto particular do processo para o precisar ${ }^{3}$.

\section{Antes ou depois de Platáo?}

Platão dedicou ao processo de Sócrates quatro obras: Eutifron, Apologia de Sócrates, Criton e Fédon. Xenofonte compôs sobre o mesmo tema os Memoráveis e a Apologia de Sócrates.

Como a data de composição dos dois discursos apologéticos continua por determinar é impossível saber quem influenciou quem. Escrita, como é óbvio, depois da morte de Sócrates, o único elemento que nos permitiria precisar a data de composiçáo da Apologia de Xenofonte seria o facto de o próprio autor deixar entender, no parágrafo 31, que, por essa altura, também Ânito falecera já. Infelizmente, este dado não é mais conclusivo, uma vez que também desconhecemos a data da morte de Ânito. No seu discurso Contra os comerciantes de milho (22.8-9), Lísias refere um Ânito que, no ano de 387, exercia funções de sitophylaks ${ }^{4}$. Mas, de acordo com a

${ }^{3}$ Esta era já a posiçáo de H. von Armin (1923, apud apud Tovar 1957:14 e n.2), que estabelecia a seguinte linha cronológica: Apologia de Xenofonte > Apologia de Platão > Memoráveis.

${ }^{4}$ Ao contrário do que acontecia com outros bens, o comércio de cereais, que não abundavam na economia ática, estava regulamentado por leis específicas (cf. Plutarco, Sólon, 24; Aristóteles, Constituição de Atenas, 51.3-4), nomeadamente quanto às quantidades que podiam ser adquiridas por cada revendedor, e era supervisionado por magistrados especialmente destacados para essas funçóes: os sitophylakes, que inspeccionavam a venda de trigo, e os inspectores do porto comercial. 
Prosopographia Attica de Kirchner (1.90), conhecem-se pelo menos seis Ânitos, no período de que tratamos. Não sabemos, pois, se podemos, ou não, identificar o Ânito de Lísias com o acusador de Sócrates5.

Se é verdade que, remetendo para um mesmo episódio, não possamos estranhar pontos óbvios de contacto entre os dois textos, é preciso não esquecermos também que em ambos se reproduz não um discurso real, e sim a sua recriação, marcada certamente pelos aspectos que, na sua recepção, mais impressionaram os seus autores: não é Sócrates quem fala, são os seus ouvintes que contam o que o ouviram dizer.

Há, entre os dois relatos, diferenças consideráveis: a ordem de formulação do texto de acusação, o papel atribuído ao daimonion (ao contrário do Sócrates de Platáo, o Sócrates de Xenofonte aparece, aqui como em Memoráveis, como um homem inspirado), a contraproposta à pena, as razóes de Sócrates, as profecias finais a que alude Xenofonte. Mas, estas divergências, contudo, não são propriamente de relatos ou episódios, mas da sua interpretação, e é preciso ter em conta que no caso de Xenofonte ele estava a receber as informaçóes em segunda mão ${ }^{6}$.

${ }^{5}$ Esse é de resto um problema comum, suscitado pelos hábitos da onomástica grega, onde por norma o filho mais velho tinha o nome do avô (às vezes, o do pai) e depois iria legá-lo também a um filho ou a um neto, tornando bastante difícil, na ausência de referências mais concretas, precisar a qual dos membros de uma mesma família aludem os testemunhos antigos.

${ }^{6} \mathrm{O}$ que faz pensar que poderá ser pouco provável, como dizem autores (que Zaragoza 1993:363, segue sem, contudo, os nomear), que Xenofonte pretendesse corrigir as informaçôes de Platão. 
Quanto a repetiçôes, como as referências à figura de Palamedes (Platão, Apologia, $41 \mathrm{~b}$ e Xenofonte, Apologia, 26) ou à tristeza de Apolodoro (Platão, Fédon, 59a; Xenofonte, Apologia, 28) não vejo porque as entender como uma imitação e não apenas como a confirmação da historicidade dos episódios.

\section{O PROPÓSITO}

Xenofonte diz, no seu texto (22-23), que não pretende fazer um relato exaustivo do processo contra Sócrates. O seu objectivo com este pequeno opúsculo seria basicamente explicar porque é que Sócrates não se defendera perante os juízes e, em última instância, com em Memoráveis, ilibar a memória do mestre. $\mathrm{O}$ velho filósofo estava já em idade avançada e não teria julgado necessário prolongar uma vida que fora feliz e frutífera com os sofrimentos que incondicionalmente acompanham a velhice (5-7) e toda a sua vida mostrava como fora ele o melhor dos homens.

Lembro, a propósito, as palavras de Gray (1998:25): «já não está em causa que Xenofonte tenha sido capaz de entender a metodologia socrática ou a sua doutrina mas a razão pela qual escolheu apresentá-lo do modo como o faz».

Julgo, em resposta a esta observação, que muito provavelmente Xenofonte não disse, nem aqui nem em Memoráveis, o que sabia sobre Sócrates, mas o que, desse conhecimento, lhe interessava efectivamente transmitir. Deste retrato de um Sócrates sem defeitos tinha de ser excluído, evidentemente, tudo o que pudesse ser polémico. 
Há, em Xenofonte, uma clara admiração pelo filósofo. Não deixa de ser possível que, ausente por altura da sua morte, ela tenha deixado nele um sentimento a que nós chamaríamos uma nostalgia de Sócrates, que o levou a empenhar-se de um modo quase radical na reabilitação da sua memória, como fica claro no epílogo da obra (34).

\section{O TeXTo}

\section{Estrutura}

Podemos encontrar na Apologia uma estrutura tripartida $^{7}$ :

$\mathrm{Na}$ Introdução (1-2), o autor apresenta as razóes que o levam a compor o texto e a fonte das suas informaçóes. Xenofonte alerta para o facto de outros autores terem abordado o assunto que vai tratar, a altivez de Sócrates durante o seu processo em tribunal, mas de ele continuar a não estar bem explicado. O que vai repetir, ouviu-o de Hermógenes, o filho de Hiponico.

${ }^{7}$ Ollier (1972:84) e, na sua esteira, Zaragoza (1993:361-362) definem para o texto também três partes, mas com a seguinte sequência: $\$ \$ 1-9$, onde Xenofonte apresenta os seus objectivos, a sua fonte e as razóes que levaram Sócrates a não se defender diante dos juízes; $\$ \$ 10-26$, que reproduz a parte da narraçáo de Hermógenes correspondente ao julgamento e a resposta de Sócrates aos juízes, e $\$ \$ 27-34$, altura em Sócrates abandona o tribunal e epílogo de Xenofonte. Prefiro, contudo, considerar como Introdução e Conclusão apenas os parágrafos em que Xenofonte se dirige ao público, exprimindo a sua opinião, e incluir no corpo do texto toda a parte narrativa de Hermógenes. 
O Corpo do texto (3-30) reproduz, entâo, a narração feita por Hermógenes dos factos ocorridos em 399 e é possível dividi-lo também em três momentos:

\$\$ 3-9: Antes do julgamento. Sócrates explica a Hermógenes o seu desinteresse pelo processo: a) considera desnecessário defender-se em tribunal, pois não é culpado e toda a sua vida pode prová-lo; além do mais, já é velho e é destino de qualquer mortal morrer um dia; b) o daimonion também lhe desaconselhou, por razóes que não nos são ditas, uma defesa formal.

$\$ \$ 10-21$ : Sócrates no tribunal. Sócrates responde à dupla acusação (10) que lhe é formulada: a) não é ímpio porque sempre respeitou os ritos e a religião de Atenas e nunca adorou qualquer novo deus; a voz que o inspira não é diferente de qualquer oráculo, e esses todos os Gregos os consultam (11-18); b) nunca corrompeu ninguém e os conselhos que dava aos que o acompanhavam eram sobre educação, matéria para a qual estava mais habilitado do que outros, familiares e amigos (19-21).

O processo de exposição dos argumentos refutativos é idêntico ao utilizado em Memoráveis, 1.1-2: apresentação do enunciado da graphê ou 'texto de indiciação' (corrupção + impiedade), refutação das acusaçôes pela ordem inversa à da sua apresentação (impiedade + corrupção).

$\$ \$ 22-30:$ Depois do julgamento. 1. Discurso final de Sócrates depois da condenação; o filósofo recusa fixar a si próprio uma pena, porque seria admitir a culpa num crime que não cometeu. 2. Sócrates abandona o tribunal: a) episódio do choro dos discípulos; b) episó- 
dio de Apolodoro; c) episódio de Anito; d) previsão da desgraça futura para aqueles que o condenam.

Na Conclusão (31-34), é de novo Xenofonte que se dirige ao público emitindo o seu juízo sobre o relato que ouviu e seu louvor pessoal a Sócrates.

Àqueles que acusam a obra de mediocridade responde Ollier (1972: 89) dizendo que o texto é um texto onde «encaixa tudo, e náo sem habilidade, de maneira lógica, simples e natural». Parece-me fundamental acrescentar a esta opinião que é também um texto que serve o propósito para o qual foi redigido; deixemos de lado se a justificação de Xenofonte correspondem ou não a uma verdade histórica: dentro do contexto ficcional da obra, ela é verosímil, aceitável e exposta com clareza e precisão.

\section{O papel de Hermógenes}

Hermógenes é a única fonte referida por Xenofonte como origem das suas informaçóes.

Meio-irmão, provavelmente bastardo, do famoso Cálias e de Hiparete (que foi mulher de Alcibíades), Hermógenes, o filho de Hiponico, não parece, contudo, ter tido a sorte de partilhar da fortuna do pai, que tornou milionário o seu célebre irmão.

Referido de modo constante nos diálogos socráticos de vários autores, resulta, pois, bastante provável que tenha sido um dos mais próximos companheiros de Sócrates, de quem seria coetâneo (teria nascido talvez por volta do ano de 455; Souto Delibes, 1999:63).

Xenofonte descreve-o (Memoráveis, 2.10) como 
um homem pobre (embora talvez mais por fracasso do que por opção; cf. Platão, Crátilo, $384 \mathrm{c})^{8}$, sério e sisudo e profundamente religioso (Banquete, 4.46-49, 8.3; cf. Platão, Crátilo, 396d, 399a, 409d; Eutifron, passim). Terá sido também um intelectual de grande cultura (Platão, Crátilo, 386a, 386d, 400a), dedicado ao estudo da linguagem. Diógenes Laércio (3.6) refere-o também como mestre de Platão e diz $(2.106$; 3.6) que, como outros socráticos, poderia ter-se refugiado, depois de 399, junto de Euclides de Mégara.

Em Platão, não é referida a sua presença no tribunal (Apologia, 33d-34a), mas acompanha os últimos momentos do mestre (Fédon, 59b), testemunho coincidente com este de Xenofonte, que o apresenta como fonte das informaçóes que constam do seu opúsculo de defesa e também do relato (de idêntico teor) de Memoráveis, 4.8.4.

É certo também que o facto de estar informado destes acontecimentos e a sua preocupação com a imagem de Sócrates, mostram que Xenofonte não perdera o contacto com Atenas. Caso contrário, porque teria escrito os Memoráveis, dirigindo-se aos Atenienses com o intuito de os fazer entender que estavam errados no

${ }^{8}$ Este testemunho de Ésquines, não parece contudo positivo, apresenta-o essencialmente como um escravo do dinheiro; referências igualmente pejorativas parecem ter sido feitas por este autor a outros membros do círculo socrático, como Cálias ou Critóbulo, de quem diz que é sujo e estúpido (Ésquines, Telauges, fr. 44 Dittmar); cf. Guthrie 1975: 319,n.19, e, de acordo com ele, H. Dittmar, Aischines von Sphettos: Studien zur Liteturgeschichte der Sokratiker (Berlín, 1912), 193 ss. e Field, Plato \& Contemp., pp.146-152 
modo como julgaram o filósofo? Não é fácil, contudo, saber como é que obtinha estas informaçóes: esteve Xenofonte em Mégara, como os outros socráticos, depois da morte de Sócrates? Regressou a Atenas? Visitou-o Hermógenes, que à data já não seria novo, no seu exílio espartano de Cilunte? As informaçóes eram trocadas através de correspondência escrita? Baseia-se Xenofonte nas tais outras obras que refere acerca do processo?

$\mathrm{Na}$ realidade, é pouco relevante para o resultado que se pretende com a narraçáo de Hermógenes que ela tenha ou não ocorrido num momento histórico real. É um facto que, tendo estado ausente na época do processo, Xenofonte teve de o conhecer através de uma outra pessoa e a presença de Hermógenes torna mais credível as informaçôes que a seguir transmite ao público leitor.

Não esqueçamos também que o próprio Platão nunca se apresenta como testemunha directa dos seus relatos (salvo na Apologia, 34a) e nalguns casos nem poderia tê-lo sido, e é precisamente através de testemunho indirecto que descreve a morte de Sócrates, que ele não presenciara, no Fédon, e ninguém duvida, contudo da autenticidade das suas informaçôes (Dorion 2000: xxxix-xi). 
APOLOGIA DE SÓCRATES 
Acho que vale a pena, também ${ }^{1}$, recordar o modo como Sócrates, quando foi chamado a comparecer diante da justiça, deliberou sobre a sua defesa e sobre o término da sua vida. É verdade que já outros escreveram sobre este assunto e que todos coincidiram na altivez da sua linguagem, pelo que se torna óbvio que foi assim que Sócrates falou; mas não deixaram suficientemente claro que ele tinha concluído que, para ele a morte era já uma escolha melhor do que a vida. Sem este pressuposto, a altivez da sua linguagem parece ser bastante insensata. Contudo, Hermógenes, o filho de Hiponico, e seu companheiro, referiu-me a seu respeito algo que mostra que essa linguagem altiva ia ao encontro do que ele pretendia. Contou-me ele que, ao ver que Sócrates falava de qualquer outro assunto mais do que do próprio julgamento, lhe perguntou:

- Não deverias, Sócrates, examinar os argumentos com os quais te hás-de defender?

A essas palavras, começou ele por responder:

- Não achas que tenho passado a minha vida a preparar essa defesa?

Ao que o outro contestou:

- Como assim?

1 Também traduz a partícula $\delta \dot{e}$, do original grego, pretendendo dar a mesma ideia de continuidade a um discurso já antes começado. Contudo, no caso presente, a existência deste recurso parece náo implicar que o texto pudesse ter alguma parte inicial perdida, mas poderá ser tomada apenas como um traço característico de coloquialidade própria do estilo de Xenofonte e que podemos encontrar também noutras das suas obras (cf. Ollier 1972: 7): S’é inicia o Económico e a Apologia, ả $\lambda \lambda \grave{a}$ o Banquete e a Constituição dos Lacedemónios. Cf. Denniston, The Greek Particles, 21 e 172. 
- Porque nunca cometi qualquer acção injusta, e é esse comportamento que eu considero, precisamente, a melhor maneira de preparar uma defesa.

Ele $^{2}$, contudo, insistiu:

- Mas, não vês como, muitas vezes, nos tribunais atenienses, por causa de um discurso, condenaram aqueles que não cometeram qualquer injustiça, e como, pelo contrário, muitas vezes também absolveram os culpados, ou porque se compadeceram com o seu discurso ou porque falaram de modo mais agradável?

— Mas, sim, por Zeus! — respondeu ele — E até por duas vezes, já, tentei ocupar-me da minha defesa, mas o divindade ${ }^{3}$ não mo permitiu.

Ele, então, exclamou:

- Que coisas mais espantosas dizes!

Ao que Sócrates, por sua vez, replicou:

- Que consideras tu que há de espantoso em que também o deus ache que é melhor para mim morrer agora? Não sabes que até este momento tenho considerado que nenhum homem usufruíra de uma vida melhor do que a minha? E, o que é mais agradável ainda, eu tinha consciência de ter vivido toda a minha vida com piedade e com justiça, de modo que, tendo por mim próprio grande estima, sentia que aqueles que conviviam comigo me consideravam de igual modo. Agora, 6 pelo contrário, se a minha idade continuar a prolongarse, sei que será necessário que sofra as consequências da velhice: ver pior, ouvir menos, ser mais lento a apren-

\footnotetext{
${ }^{2}$ Refere-se a Hermógenes, o narrador da conversa que se segue.

${ }^{3}$ Em grego, to daimonion.
} 
der e mais esquecido do que aprendi. Ora, se tiver esta percepçáo de que me tornarei mais fraco - continuava Sócrates - e tiver de me censurar a mim mesmo, como é que poderei continuar a viver com gosto? Mas talvez o $\quad 7$ deus — dizia ainda —, na sua benevolência, me esteja a facultar não só o momento mais agradável, na minha idade, para dar por concluída a minha vida, como também a morte mais fácil ${ }^{4}$. De facto, se me condenarem agora, é óbvio que me será aplicada a morte que é tida como a mais fácil por aqueles que se dedicam a estas matérias, a menos penosa para os meus amigos, a que traz a maior saudade pelos mortos, porque não deixa lembrança, nem de vergonha nem de pena, no pensamento dos companheiros; antes, póe término à vida enquanto o corpo e a alma ainda têm capacidade de demonstrar entendimento. Como é que não será forçoso que se sintam saudades de quem morre nestas circunstâncias? Com razão — insistia ele — se opunham os deuses a que me ocupasse do meu discurso de defesa, na altura em que tínhamos por indispensável, a todo o custo, encontrar como fugir. Porque se tivesse conseguido, é óbvio que, em vez de abandonar já a minha vida, estarme-ia a preparar para morrer afligido pelas doenças ou pela velhice, à qual acorrem todas as dificuldades, numa total privação de alegrias. Não, por Zeus, Hermogénes - afirmara-lhe —, não serei eu que vou ansiar por uma tal situação; antes, acredito que todas essas vantagens as recebi dos deuses e dos homens, incluindo a opiniáo

${ }^{4}$ Morte pela cicuta. 
que tenho de mim mesmo, e se por causa de tais benefícios desagrado aos juízes, então, antes prefiro morrer a viver servilmente, mendigando o benefício de uma vida muito pior do que a morte.

Contava ele, ainda, que fora com estas apreciaçôes que, quando os seus adversários no julgamento o acusaram de não reconhecer os deuses que a cidade reconhece ${ }^{5}$, e de, em sua vez, introduzir novas divindades e corromper a juventude ${ }^{6}$, se apresentou diante dos juízes e disse:

- Eu, meus senhores, em primeiro lugar, interrogo-me, perplexo, sobre qual o conhecimento de Meleto ${ }^{7}$ para afirmar que eu não reconheço os deuses que

${ }^{5}$ Em grego, theous nomizdein: 'honrar os deuses' de acordo com as normas estabelecidas pela cidade ou 'acreditar nos deuses' da cidade (cf. Brickhouse-Smith 1989: 30-34, W. Burkert, Religião grega de época clássica e arcaica (Lisboa, 1993), , e È. de Stycker-S. R. Slings, Plato's Apology of Socrates (Leiden, 1994), 87-88). Sigo a tradução sugerida por Dorion (2000:49,n.2), 'reconhecer os deuses', que permite abranger os dois significados e ser interpretado como o interpretam os discípulos ao rebater os argumentos do processo: Xenofonte insiste em que Sócrates era um crente praticante (Memoráveis, 1.1.2-4; Apologia, 11), mas também um crente simplesmente (1.1.5); para Platão, Sócrates era um crente, mas também seguia os rituais estabelecidos para a prática dessa crença (cf. Fedro, $279 b-c)$.

${ }^{6}$ São estas mesmas acusaçóes as que vamos encontrar desenvolvidas em Xenofonte, Memoráveis, 1.1-2; em Platão, Apologia, 24b-c, Eutidemo, 2c-3b, e Diógenes Laercio, 2.40. Embora as versóes divirjam ligeiramente, na escolha do vocabulário utilizado, a formulaçâo é idêntica.

${ }^{7}$ Meleto era poeta, ao que parece tragediógrafo. O nome era comum, pelo que não é possível confirmar se serão da sua autoria todos os fragmentos que se lhe atribuem (Aristófanes, frs. 114, 149-150, 438 K.-A.); um outro Meleto, também poeta, seria talvez seu pai e está por resolver se seria ele o mesmo Meleto que, igualmente no ano de 399, levou a julgamento o orador Andócides (Aristófanes, escólio a Râs, 1302). É Meleto quem 
a cidade reconhece. É que qualquer um dos que aqui estão presentes, incluindo o próprio Meleto, quando queriam, podiam ver-me a fazer sacrifícios nas festas da cidade e nos altares públicos. E quanto às novas divindades, será que consideraram que as introduzia, ao dizer que a voz de deus se manifesta para me dar sinais sobre o que devo fazer? Ora, os que consultam os gritos das aves e as palavras dos homens também baseiam em vozes as suas decisóes. Alguém discutiria que os trovôes não sejam vozes ou o mais importante dos presságios? E a sacerdotisa que tem o seu assento na trípode de Delfos, não anuncia, também ela, a mensagem do deus através da voz? Antes, que o deus conhece o futuro e está disposto a transmiti-lo a quem ele quiser, isso também, tal como eu o digo, todos o dizem e todos o crêem. Mas enquanto os outros chamam augúrios, vozes, casualidades e profetas àqueles que lhes enviam sinais, eu chamolhe divindade, e penso que, chamando-lhe assim, o faço com maior verdade e com maior piedade que os que atribuem às aves o poder dos deuses. E esta é a prova de que não estou a mentir em relação ao deus: tendo anunciado a muitos dos meus amigos os seus sinais, em nenhum caso pareceu que me tivesse enganado.

Ao ouvir estas palavras, os juízes protestavam, uns por desconfiarem das suas afirmaçóes e outros invejosos por ele obter dos deuses mais favores dos que eles conse-

interpõe a acção contra Sócrates (Platão, Apologia, 23e; Eutifron, 2a-3a; Xenofonte, Memoráveis, 4.4.4, 4.8.4), junto de Laques, Arconte nesse ano, mas provavelmente seria apenas um porta-voz. Platão descreveu-o, no $\hat{E} u$ tifron (2b), como um jovem, pouco conhecido. 
guiam, e Sócrates continuava:

- Mais, escutai ainda o seguinte, para que aqueles que de entre vós o queiram, desconfiem ainda mais da graça com que fui honrado pela divindade. Certo dia, Querefonte dirigiu-se ao oráculo de Delfos para o interrogar a meu respeito, na presença de grande número de testemunhas, e Apolo respondeu-lhe que nenhum homem era mais livre, nem mais justo, nem mais sensaIs to do que $\mathrm{eu}^{8}$.

E como, de novo, ouvindo esta resposta, os juízes pareciam agitar-se ainda mais, Sócrates prosseguiu:

- Contudo, meus senhores, o deus disse coisas muito mais importantes sobre Licurgo ${ }^{9}$, o legislador dos Lacedemónios, do que a meu respeito. Conta-se, pois, que, ao entrar no templo, se lhe dirigiu assim: «Hesito se devo chamar-te deus ou homem». A mim não me comparou com um deus, mas soube avaliar que me distinguia em muito dos homens. Mesmo assim, não é por essa razão que tendes forçosamente de acreditar no deus, I6 antes, deveis examinar cada uma das palavras que o deus proferiu. Em primeiro lugar, quem é que conheceis, que seja menos escravo do que eu dos desejos do corpo? E que outro homem conheceis mais livre do que eu, que não recebo de ninguém nem ofertas nem salário? E a quem, com razão, consideraríeis mais justo do que esse que assim se contenta com o que tem e não necessita de

${ }^{8}$ Cf. Platão, Apologia, 20e-21a: Platão é mais comedido; Querofonte pergunta se algum homem é mais sábio que Sócrates; o oráculo simplesmente responde-lhe que não. Cf. também Memoráveis, 2.4 e Platão, Cármides, $153 \mathrm{~b}$.

\footnotetext{
${ }^{9}$ A mesma história é contada por Heródoto, 1.65.
} 
qualquer bem alheio? E como seria possível, com razão, alguém dizer que eu não sou um homem sábio, eu, que desde o tempo em que comecei a compreender o que se dizia, nunca mais deixei de investigar e aprender tudo quanto de bom pude? E quanto à eficácia do meu trabalho, não vos parece também que é uma prova o facto de muitos cidadãos que procuram a virtude, e também muitos estrangeiros preferirem, de entre todos, acompanhar-me a mim? E qual diríamos que é a causa para o facto de que, mesmo sabendo todos que eu não tenho bens para retribuir, muitos estejam, no entanto, dispostos a trazer-me ofertas? Ou até que ninguém reclame de mim a retribuição de nenhum favor e, pelo contrário, muitos concordem que devem estar-me agradecidos? $\mathrm{Ou}$ que durante o cerco ${ }^{10}$, enquanto outros lamentavam a sua sorte, eu continuei sem maiores dificuldades do que quando a cidade gozava de mais prosperidade? Ou porque é que os outros procuram, na ágora, iguarias a preços exorbitantes, enquanto eu consigo extrair da minha alma prazeres mais agradáveis do que esses, sem qualquer custo? E se, em verdade, ninguém pode refutar nada do que eu disse sobre mim mesmo, argumentando que estou a mentir, como é que agora não seria justamente elogiado tanto pelos deuses como pelos homens?

E mesmo assim, dizes-me tu, Meleto, que, com este comportamento, eu corrompo os jovens? Ora bem, nós sabemos qual o tipo de corrupçóes que afectam os

${ }^{10} \mathrm{O}$ cerco que, no último ano da Guerra do Peloponeso, Esparta impôs a Atenas. 
jovens. Diz-nos, então, se conheces algum jovem que por minha causa tenha passado de pio a ímpio, de sensato a insolente, de moderado a gastador, de pouco bebedor a alcoólico, de trabalhador a indolente, ou tenha 20 ficado na dependência de algum outro prazer perverso. — Por Zeus! — respondeu Meleto — Eu sei de pessoas às quais convenceste a que te obedecessem mais a ti do que aos próprios pais.

- Concordo - anuiu Sócrates - Pelo menos, no que diz respeito à educação, pois sabem que essa é a área pela qual me interessei. Mas, no que diz respeito à saúde, as pessoas também obedecem mais aos médicos do que aos pais, e também nas assembleias quase todos os Atenienses obedecem mais àqueles que falam com sensatez do que aos parentes. Além disso, não escolheis também para generais, em vez dos vossos pais ou irmãos, ou, por Zeus, de vós mesmos, aqueles que julgais ter mais conhecimento na arte da guerra?

— É verdade, Sócrates, porque assim convém e 2 I assim se tem por certo.

- Pois também neste caso - continuou Sócrates -, não achas espantoso que, enquanto nas restantes actividades, aqueles que mais sobressaem não só obtêm os mesmos direitos como recebem as mais altas honras, eu, pelo contrário, porque alguns me consideram melhor no que é o mais importante dos bens para o homem, a educação, receba de ti uma acusação

22 punível com a morte?

É evidente que muitas outras coisas foram ditas, tanto por ele como pelos amigos que testemunharam 
em sua defesa ${ }^{11}$, mas eu não me proponho contar tudo quanto foi exposto no processo; antes, basta-me, acima de tudo, mostrar que Sócrates não cometera nenhum dos crimes de que era acusado: nem fora ímpio para com os deuses nem se mostrara injusto com os homens. E nem pensara em mediante súplicas evitar a morte; antes, considerava até que esse era o momento propício para deixar terminar a sua vida. Que era assim que ele pensava, tornou-se suficientemente claro quando a sentença foi negativa, pois, em primeiro lugar, quando foi chamado a fixar a sua parte da pena, não quis fazê-lo pessoalmente nem deixou que o fizessem os seus amigos, e replicou que fixar a si próprio uma pena significaria concordar que era culpado. Depois, quando os companheiros quiseram tirá-lo da cadeia às escondidas, não o consentiu, e até pareceu zombar deles ao perguntar-lhes se conheciam algum lugar fora da Ática que não estivesse ao alcance da morte.

E quando o julgamento chegou ao fim, concluiu:

- Ora, meus senhores, aqueles que instruíram as testemunhas indicando-lhes que deviam testemunhar falsamente contra mim e os que se deixaram persuadir por eles devem ter a noção de que cometeram contra eles mesmos um crime grave de impiedade e uma enorme injustiça. Quanto a mim, porque me hei-de sentir agora menos orgulhoso do que antes de ser condenado, já que ninguém me convenceu de ter cometido nenhum dos crimes de que me acusaram? Porque, a mim, nunca

${ }^{11}$ Cf. Platão, Apologia, 34 a. 
me viram fazer sacrifícios a novas divindades em vez de os fazer a Zeus, Hera e aos deuses que os acompanham,

25 nem jurar por outros deuses nem invocá-los. E quanto aos jovens, como é que poderia corrompê-los, habituando-os à perseverança e à frugalidade? E quanto aos crimes passíveis de pena de morte, o saquear de templos, arrombar casas para as assaltar, escravizar homens livres, trair a cidade, nem sequer os meus próprios adversários me acusam de ter cometido algum deles ${ }^{12}$. Por essa razão me pergunto, perplexo, como puderam achar que 26 eu tinha cometido algum crime merecedor da morte. Contudo, não é por morrer injustamente que tenho de me mostrar menos orgulhoso, porque a vergonha não é minha mas daqueles que me condenaram. Consolame a lembrança de Palamedes, que teve um fim muito parecido com o meu. Até hoje continua a inspirar hinos muito mais belos que os de Ulisses, que injustamente lhe causou a morte ${ }^{13}$. Sei que também testemunharão a

${ }^{12}$ Cf. Memoráveis, 1.2.62-63.

${ }^{13}$ Cf. Memoráveis, 4.2.23. Também o Sócrates de Platão diz o mesmo em Apologia, 41b.

$\mathrm{O}$ argivo Palamedes fora o responsável pela participação de Ulisses na Guerra de Tróia. Embora, no passado, tivesse sido Ulisses o mentor do pacto entre os pretendentes de Helena, quando Menelau convocou a expedição destinada a reaver a mulher e punir os Troianos, o rei de Ítaca mostrou-se indisponível para o acompanhar, fingindo ter enlouquecido. $\mathrm{O}$ logro foi desmascarado por Palamedes, sobre quem Ulisses jurou vingança. Ao fim de dez árduos anos de guerra e já próximo do seu fim, Ulisses consegue, através de ardilosos enganos, incriminar Palamedes de traição à causa grega. Não tendo conseguido provar a sua inocência, o guerreiro foi lapidado pelos Aqueus.

Quando, sobretudo a partir do século V, o aspecto engenhoso do carácter de Ulisses começa a ser visto de modo ambíguo (cf. Sófocles, Filoctetes, 
meu favor quer o tempo que está para vir, quer o tempo passado, demonstrando que nunca causei mal a ninguém nem tornei nenhuma pessoa pior; antes fazia bem aos que falavam comigo, ensinando-lhes gratuitamente tudo quanto de bom podia.

Depois deste discurso, retirou-se com ar, atitude e 27 passo fulgente, em tudo a condizer com as palavras que acabava de proferir. Mas ao perceber que os seus companheiros choravam, perguntou:

- Que se passa? Agora é que vos dá para chorar? Por acaso não sabiam há muito tempo que, desde o dia em que nasci, estava sentenciado, pela natureza, à morte? Claro que, se estivesse a morrer novo, enquanto podia gozar ainda de muitos bens, é óbvio que teríamos de nos lamentar, tanto eu como os que me fossem

Eurípides, Ifigénia em Áulide, Platão, Hipias Menor), os escritores parecem ter mostrado particular empenho em reabilitar a figura do seu inimigo de outrora, cuja morte se tornara o paradigma da morte injusta; para além destas sumárias referências de Sócrates, ficou célebre o (infelizmente perdido) texto do sofista Górgias, Em Defesa de Palamedes. Também Ésquilo, Sófocles e Eurípides teriam composto Palamedes, dos quais se conserva um único fragmento (Eurípides, fr.588 Nauck).

As referência que Sócrates faz ao caso de Palamedes aproximam-se mais do texto de Górgias do que do mito tradicional (cf. J. Morr, «Des Gorgias Palamedes und Xenophon Apologie», Hermes 61 (1926), 467 ss). Há também algumas possibilidades de que a doutrina de Sócrates fosse em parte devedora da de Górgias; cf. G. Caloguero «Gorgias and the Socratic Principle Nemo Sua Sponte Peccat», JHS 77 (1957), 12-17.

Para James A. Coulter, «The relation of the Apology of Socrates to Gorgias' Defence of Palamedes and Plato's Critique of Gorgianic Rhetoric, HSCPh 68 (1964), 269-303 [302, n.6], esta passagem seria pouco relevante e dela poder-se-ia concluir apenas que Xenofonte lera Platáo e teria considerado lógica a referência, comum no seu tempo, aos hinos em honra de Palamedes. 
próximos; mas, pelo contrário, se, tendo atingido a idade limite, liberto a minha vida das dificuldades que me esperam, julgo que todos devem ficar felizes por eu ter esta boa oportunidade.

Estava presente um tal Apolodoro ${ }^{14}$, seguidor fervoroso de Sócrates, mas em tudo o mais uma pessoa simples, que disse:

- Mas, Sócrates, a mim o que me traz maior pesar é ver-te morrer injustamente.

Sócrates, então, pelo que se conta, respondeu-lhe, fazendo-lhe uma festa na cabeça:

- Preferias tu, então, meu querido Apolodoro, ver-me morrer com justiça a sem justiça?

E, com a pergunta, sorria.

29 E conta-se, ainda, que, ao ver Ânito passar, comentou:

- Eis um homem cheio de orgulho, convencido de que realizou uma grande e bela proeza, por ter conseguido que me matassem, porque, ao ver que a cidade lhe concedia grandes honras, disse-lhe que não devia educar o filho no ofício de curtidor ${ }^{15}$. Que triste sujeito

${ }^{14}$ Apolodoro de Faléron, amigo de Sócrates, o seu entusiasmo pelo filósofo valera a alcunha de «maníaco», louco; ter-se-ia oferecido para pagar a multa exigida em tribunal pela libertação do mestre. Cf. Platão, Banquete, 172b-c; Fédon, 59a-b,117d; Xenofonte, Memoráveis, 3.2.17.

15 Ânito também era curtidor, pelo que seria absolutamente corrente, no contexto ateniense, que o filho aprendesse com o pai o ofício e lhe desse continuidade. Sócrates, pelos vistos, terá achado que o jovem teria capacidades para outras ocupaçóes e refere, em Platão (Ménon, 91c), que Ânito manifestara a vontade de que nenhum dos seus se tornasse discípulo dos Sofistas, entre os quais, provavelmente (como outros Atenienses; cf. Aristófanes, Nuvens, e Platáo, Protágoras), incluiria Sócrates. 
este que não parece saber que aquele que de nós os dois tenha deixado, para todo o sempre, as obras mais úteis

e mais belas, esse será o vencedor. Mas — diz-se que acrescentou - tal como Homero fez com que, no momento em que a vida as abandonava, algumas das suas personagens ganhassem dons proféticos ${ }^{16}$, também eu

Ânito é tradicionalmente apontado como o verdadeiro mentor do processo, a partir de uma observação de Sócrates, que, na Apologia de Platáo (18b), usa a expressão Ânito e os do seu grupo, para se referir aos seus acusadores; a suposição é corroborada por Diógenes Laércio, 2.38.

Era um cidadão importante, pertencente a uma família de ricos comerciantes de curtumes (Platão, Ménon, 90a; escólio a Platão, Apologia, 18b). Fora general ao serviço de Atenas, durante a guerra do Peloponeso, e enfrentara um processo por traiçáo depois da derrota de Pilos (Aristóteles, Constituição de Atenas, 27.5). O seu destaque na cena política ateniense devia-se sobretudo ao papel desempenhado na revolta democrática de 403 contra o domínio dos Trinta Tiranos, onde ganhara a simpatia popular por não ter querido ser compensado dos prejuízos económicos que sofrera durante a oligarquia. Contudo, tendo sido um dos subscritores da referida Amnistia de 403 (Aristóteles, Constituição de Atenas, 34.3), parece pouco provável que as razóes que o levaram a acusar Sócrates se prendessem com as críticas do filósofo às instituiçóes democráticas. Ele próprio seria um moderado, o que não faria dele um defensor fervoroso da democracia popular (Erbse 1961:261).

Platão apresenta, no Ménon (89e-95a), razóes possíveis para a animosidade entre os dois homens, que poderia ser motivada pelas posiçóes de Sócrates acerca dos políticos democráticos, mas, mais provavelmente, pelo relacionamento estabelecido entre Sócrates e o filho de Ânito, a que Xenofonte alude na Apologia (29-31); aparece também, no mesmo texto de Platáo, como um radical opositor aos Sofistas. Xenofonte testemunha aqui, na Apologia (31), o descrédito que a figura de Ânito sofrera devido à sua participaçáo na morte de Sócrates (cf. Plutarco, 18.762d) e uma tradição duvidosa (Temístocles, 20.239c), herdeira talvez do testemunho de Diógenes Laércio (2.43), refere que teria sido exilado por essa mesma razão e teria sido morto nesse exílio, em Heracleia.

${ }^{16}$ Cf. Ilíada, 16.851-854: Pátroclo prevê a morte de Heitor; 22.358360: Heitor prevê a morte de Aquiles. Também em Platão, Apologia, 39c. 
agora quero fazer uma profecia:

Tive, em tempos, um breve contacto com o filho de Ânito e pareceu-me que não era fraco de espírito, pelo que asseguro que não ficará muito tempo na vida servil que o pai lhe reservou; mas, se não tiver nenhum 3 I conselheiro diligente, cairá nalguma paixão vergonhosa e há-de ter uma promissora carreira de perversidades.

E não se enganou nestas previsóes: o rapaz, de facto, tomou gosto pelo vinho e não parou mais de beber, dia e noite, e acabou por não ter qualquer préstimo, nem para a cidade, nem para os seus amigos, nem para ele próprio. Ânito, por sua vez, devido à péssima educação que deu ao filho, e à sua falta de juízo, ainda agora, depois de morto, goza de má fama.

Ao elogiar-se a si próprio diante do tribunal, Sócrates despertou a inveja dos juízes e tornou-os ainda mais veementes na sua condenação. A mim, contudo, parece--me que completou um destino grato aos deuses,

33 pois evitou a parte mais penosa da vida e encontrou a mais fácil das mortes. Deu assim provas da força do seu espírito, pois, tendo percebido que para ele era preferível morrer a continuar a viver, tal como nunca rejeitara outros bens da vida, também não se mostrou cobarde diante da morte e aceitou-a e recebeu-a com alegria.

$\mathrm{Eu}$, por minha vez, ao reflectir sobre a sabedoria e nobreza de espírito daquele homem, não posso deixar de o lembrar, e, ao lembrá-lo, de o elogiar. Se algum dos que aspiram à virtude tiver conhecido alguém que lhe tenha trazido mais benefícios do que Sócrates, julgo que esse merecerá mais do que todos ser considerado um homem feliz. 


\section{Bibliografia}

\section{EDIÇŌES E TraduÇốEs:}

L.-A. Dorion (2000), Xénophon. Mémorables. Livre I. Paris.

E. C. Marchant ( ${ }^{2} 1921$; repr. 1962), Xenophon. Opera Omnia. Oxford.

F. Ollier (1972), Xénophon. Banquet-Apologie de Socrate. Paris, 81-119.

O. J. Todd (1973), Xenophon. Symposion and Apology. Londres.

A. Tovar (1957), Jenofonte. Apologia de Sócrates. Madrid.

J. Zaragoza (1993), Jenofonte. Recuerdos de Sócrates. Económico. Banquete. Apología de Sócrates. Madrid, 357-378.

\section{Estudos}

H. R. Breitenbach (1967), «Xenophon von Athen», RE, IX A 2, 1569-2052.

Th. Brickhouse e N. D. Smith (1989), Socrates on Trial. Oxford.

\section{(2002), The Trial}

and Execution of Socrates. Sources and Controversies. Oxford.

L. Brisson (2001), «Les Accusations portées contre Socrate», in G. Romeyer-Dherbey (dir.) et J.-B. Gourinat (éd.), Socrate et les Socratiques. Paris, 71-94. 
Ch. Bruell (1994), "Xenophon and his Socrates», in Amy L. Bonnette, Xenophon. Memorabilia. New York, viixxii [= 1988-1989: «Xenophon and his Socrates», Interpretation 16, 295-306].

D. Clay (1994), «The Origins of the Socratic Dialogues», in P.A. Vander Waerdt (ed.), The Socratic Movement. New York, 23-47.

J. K. Davies (1971), Athenian Propertied Families. 600-300 B.C. Oxford.

L.-A. Dorion (2000), Xénophon. Mémorables. Livre I. Paris

G. Giannantoni (1991), «Pour une édition des sources antiques sur Socrate», The Philosophy of Socrates. Atenas, 133-140.

V. J. Gray (1989), «Xenophon's Defense of Socrates. The Rethorical background to the Socratic problem», $C Q$ 39, 136-140.

(1998), The framing of Socrates: the literary interpretation of Xenophon's Memorabilia, Stuttgart.

W. K. C. Guthrie (1975), A History of Greek Philosophy. Cambridge.

W. E. Higinns (1977), Xenophon the Athenian. The problem of the individual and the society of the polis. New York.

H. Erbse (1961), «Die Architektonik im Aufbau von Xenophons Memorabilien», Hermes 89, 257-287. 
W. Jaeger (1979), Paideia. Lisboa.

Ch. H. Kahn (1996), Plato and the Socratic Dialogue. The philosophical use of a literary form. Cambridge, 1-35 e 75-79.

C. Mossé (1987), Le procés de Socrate. Paris.

O. Murray (ed.) (1994), Sympotika. A Symposium on Symposion. Oxford.

M.H. Rocha Pereira ('2003), Estudos de História da Cultura Clássica. I. Cultura Grega. Lisboa.

S. Pomeroy, Xenophon, Oeconomicus. Oxford.

F. Souto Delibes (1999), «Hermogenes Socraticus», Faventia 21/2, 57-64.

C. Viano (2001), «La cosmologie de Socrate dans les Mémorables de Xénophon», in G. Romeyer-Dherbey (dir.) / J.-B. Gourinat (éd.), 97-119. 


\section{Volumes publicados na ColecÇão Autores \\ Gregos e Latinos - Série TEXTos}

1. Delfim F. Leão e Maria do Céu Fialho: Plutarco. Vidas Paralelas - Teseu e Rómulo. Tradução do grego, introdução e notas (Coimbra, CECH, 2008).

2. Delfim F. Leão: Plutarco. Obras Morais - O banquete dos Sete Sábios. Tradução do grego, introdução e notas (Coimbra, CECH, 2008).

3. Ana Elias Pinheiro: Xenofonte: Banquete, Apologia de Sócrates. Tradução do grego, introdução e notas (Coimbra, CECH, 2008). 

OBRA PUBLICADA

COM A COORDENAÇÁO

CIENTÍFICA

0

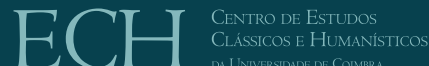

DA UNIVERSTIDAD DE COIMBRA

- $\mathbf{U}$

C •

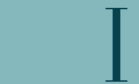

IMPRE VSA DA UNIVERSIDADE DE COINPRA 